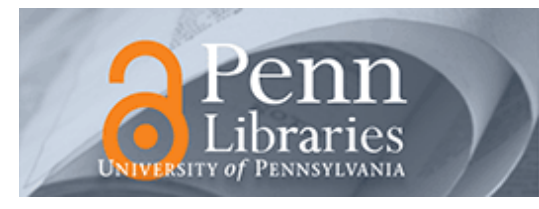

University of Pennsylvania ScholarlyCommons

2004

\title{
Corporate Financial Policies and Performance Around Currency Crises
}

Arturo Bris

Yrjo Koskinen

University of Pennsylvania

Vicente Pons

Follow this and additional works at: http://repository.upenn.edu/fnce_papers

Part of the Corporate Finance Commons, Finance Commons, and the Finance and Financial Management Commons

\section{Recommended Citation}

Bris, A., Koskinen, Y., \& Pons, V. (2004). Corporate Financial Policies and Performance Around Currency Crises. The Journal of Business, 77 (4), 749-796. http://dx.doi.org/10.1086/422438

At the time of publication, author Yrjo Koskinen was affiliated with Boston University School of Management and CEPR. Currently, he is a faculty member at the Wharton School at the University of Pennsylvania.

This paper is posted at ScholarlyCommons. http://repository.upenn.edu/fnce_papers/251

For more information, please contact repository@pobox.upenn.edu. 


\title{
Corporate Financial Policies and Performance Around Currency Crises
}

\begin{abstract}
This paper studies firm-level leverage and performance measures before and after a currency crisis, using data from 17 countries. We show that, prior to a crisis, companies that expect to benefit from currency depreciations increase their leverage more than companies that are expected to be harmed by the depreciation. Profitability and financial fragility ratios display consistent patterns. We provide evidence that the Asian crisis is different from the previous European and Latin American ones: In Asia, all firms become more fragile after the crisis and their profitability declines and leverage increases further, whereas elsewhere there are clear signs of recovery after a crisis occurs.
\end{abstract}

\section{Disciplines}

Corporate Finance | Finance | Finance and Financial Management

\section{Comments}

At the time of publication, author Yrjo Koskinen was affiliated with Boston University School of Management and CEPR. Currently, he is a faculty member at the Wharton School at the University of Pennsylvania. 


\section{Corporate Financial Policies and Performance around Currency Crises*}

Are currency crises caused by irresponsible macroeconomic policies? The answer used to be an unqualified yes: A currency crisis was a just retribution for government mismanagement. However, the 1997 crises in Asia led many observers to question this view. Most of the afflicted economies had budget surpluses and healthy foreign exchange reserves. While current account deficits were large in some countries (Thailand and Malaysia), they were very modest in others (South Korea and Indonesia). Therefore, it is difficult

* We thank George Allayannis, Mariassunta Giannetti, Loriana Pelizzon, Simon Johnson, and audiences at the Yale School of Management, Stockholm School of Economics, Norges Bank, Boston College, University of California-Irvine, University of Amsterdam, Washington University, Georgia State University, University of Georgia, Universitat de València, 2000 Economic Analysis Symposium in Barcelona, 2001 FMA European Meeting in Paris, 2001 Financial Market Development in Emerging and Transition Economies Conference in Hong Kong, 2001 EFA Conference in Barcelona, 2001 EEA conference in Lausanne, and 2002 AFA conference in Atlanta for helpful comments. Contact the corresponding author, Arturo Bris, at arturo.bris@yale.edu. Koskinen is grateful to Bankforskningsinstitutet for financial support. Vicente Pons is grateful to Fundación Ramón Areces for financial support. The authors are responsible for all remaining errors.

(Journal of Business, 2004, vol. 77, no. 4)

(C) 2004 by The University of Chicago. All rights reserved. 0021-9398/2004/7704-0005\$10.00
This paper studies firmlevel leverage and performance measures before and after a currency crisis, using data from 17 countries. We show that, prior to a crisis, companies that expect to benefit from currency depreciations increase their leverage more than companies that are expected to be harmed by the depreciation. Profitability and financial fragility ratios display consistent patterns. We provide evidence that the Asian crisis is different from the previous European and Latin American ones: In Asia, all firms become more fragile after the crisis and their profitability declines and leverage increases further, whereas elsewhere there are clear signs of recovery after a crisis occurs. 
to argue that currency depreciations were needed for macroeconomic reasons.

Recently, a literature that places the corporate sector and its leverage as the central issue in currency crises has started to emerge. Most influential among those papers have been models by Aghion, Bachetta, and Banerjee (2001) and Krugman (1999). In those papers, firms' output prices are sticky and firms finance their operations at least partially with debt denominated in a foreign currency. When shocks or loss of confidence cause an initial currency depreciation, the declining profitability and financial distress problems for corporations lead to further depreciations. Hence, in these models, a currency depreciation causes financial distress problems. The opposite view of currency depreciations is given by Bris and Koskinen (2002). In their model, exporting companies face a financial distress problem, which is solved through a currency depreciation. A currency depreciation helps solve financial distress problems even when firms have borrowed in a foreign currency, if firms' cash flows are denominated in a foreign currency and its costs at least partially in a domestic currency. A currency depreciation is not costless, however, since it leads to excessive leverage and risky investments prior to a depreciation. Schneider and Tornell (2004) have a model that allows for asymmetric firm-level developments both before and after a crisis. In their model, firms operate in either the tradable or nontradable sector. The banking sector has been given a bailout guarantee, and at the same time, financial contracts suffer from imperfect enforceability. The existence of these two distortions give rise to the willingness to extend credit denominated in a foreign currency to the firms in the nontradable sector and firms credit constrained by the extent of their net wealth. As a result, firms in the nontradable sector can grow faster and more profitably than firms in the tradable sector with an appreciating real exchange rate before a crisis and suffer more when the exchange rate collapses after a crisis.

To what extent corporate financial policies are related to currency depreciations is still an open question empirically. A currency depreciation may harm corporations financed with foreign debt, as Aghion et al. (2001) and Krugman (1999) note, and deepening financial distress is a consequence of the currency crisis. If, instead, corporations see a potential currency depreciation as a mean of resolving corporate distress problems, two main empirical predictions ensue: Financial distress precedes a currency crises, followed by improving financial health; and only those firms that benefit from the currency depreciation should display excessive leverage prior to a crisis, as emphasized by Bris and Koskinen (2002). In general, firms' leverage and profitability could develop asymmetrically before and after a crisis has occurred, as implied by the model of Schneider and Tornell (2004): Firms in the tradable sector show higher leverage and lower profitability and growth 
preceding a crisis compared to firms in the nontradable sector and a reversal of roles after a crisis has occurred.

This paper contributes to this growing literature of corporate leverage and currency crises by providing empirical evidence of corporations' financial policies and performance around currency depreciations. We analyze micro-level data from 20 countries from Asia, Europe, and Latin America. Seventeen countries in our sample (the crisis sample) experienced currency devaluations over the past decade. ${ }^{1}$ The remaining three countries (Argentina, Hong Kong, and Japan), which did not experience a currency crisis even though their currencies faced some pressure, form our control sample (no-crisis sample). In the no-crisis sample, we identify the date where the currency suffered speculative attacks, which somehow lead to severe exchange rate depreciations. This date determines the event date around which we analyze financial policies and profitability.

We first document a median $1.91 \%$ increase in corporate debt-tovalue ratios during the last 3 years prior to a currency crisis $^{2}$ for all countries. Such an increase in leverage is particularly large for European and Latin American firms. In Asia, the evidence is not that clear. In the years following a currency depreciation, we find significant increases in leverage in all countries in Asia except Hong Kong and Japan. In Europe and Latin America, the postcrisis evidence is mixed. However, we find significant differences in corporate financial policies in countries that experienced a currency crisis relative to countries that did not. Debt ratios increase by $4.43 \%$ in the first group of countries prior to the crises, but they do not change in the second group. In addition, there is an $8.35 \%$ increase in leverage after the crisis in the crisis sample countries, against a $0.72 \%$ increase (only significant at the $10 \%$ level) in the no-crisis sample.

Several theoretical explanations, already outlined, are consistent with these findings. It is also possible that the results are mere accounting artifacts: Since we also document that firm profitability declines prior to a currency crisis, a reduction in earnings could automatically increase the debt-to-value ratios. Finally, leverage increases could be completely unrelated to currency crises, only a result of the preference for debt over equity during the 1990s.

We try to provide some more evidence for and against the previous theoretical arguments. In the papers by Aghion et al. (2001), Krugman (1999), and Bris and Koskinen (2002), firms either suffer or benefit

1. Out of the 17 countries in our depreciation sample, 4 countries had strictly fixed exchange rates, 11 countries had fixed rates within a band, and 2 countries had real exchange rate target.

2. Referring to a currency crisis for the no-crisis sample is obviously a misnomer. For expositional purposes and for Argentina, Hong Kong, and Japan, "before the crisis" and "after the crisis" mean before and after the speculative attacks to their currencies, respectively. 
from a currency depreciation, depending on their exchange rate exposure. The asymmetric reaction to a currency depreciation is even more explicit in Schneider and Tornell (2004). Therefore, we first sort companies within a country into two groups, using individual companies' stock market returns. In the first group, we have companies whose stock returns decrease when the domestic currency appreciates with respect to the U.S. dollar (negative-exposure companies); in the second group, we place those companies whose stock returns increase (positive-exposure companies). The first group includes exporting firms and firms in the tradable sector in general, while the second group includes importing firms, firms financed with large amounts of foreign debt, and firms in the nontradable sector.

After sorting the companies into these two groups, we show that the companies with negative exposure have higher leverage than the companies with positive exposure; moreover, the negative-exposure companies increase their leverage more than positive-exposure companies prior to a currency depreciation. Importantly, this is only true for countries in the crisis sample. In addition, we analyze companies' profitability and financial fragility using several standard ratios and show that negative-exposure companies in particular become more fragile financially before a currency depreciation. We also find that profitability decreases for all companies before a currency crisis, but the effect is more pronounced for the negative-exposure companies. This decline in profitability could explain why leverage increases. However, we show that profitability does not explain debt ratios at the time of the currency crisis in our cross-sectional regression. In this multivariate regression framework, controlling for firm and country characteristics, we report that companies that benefit from a currency depreciation have higher leverage than companies harmed by the depreciation. Interestingly, the results are the opposite for the no-crisis sample in almost all respects: In general, positive-exposure companies fare worse than negative-exposure companies in these countries. In addition, after controlling for our measure of exchange rate exposure, we find the usual proxies for corporate governance quality to be either insignificant or with unexpected signs when used as a explanatory variables of firm leverage.

The finding that firms that benefit from a currency depreciation increased their leverage prior to the corresponding currency crisis supports the view in Bris and Koskinen (2002). The result that firms were less profitable and are more fragile even after a currency depreciation is consistent with the arguments posed by Aghion et al. (2001) and Krugman (1999). We conclude that the evidence seems to support the arguments of Bris and Koskinen (2002) in Europe, whereas the Asian crisis is more in line with Aghion et al. (2001) and Krugman (1999). In general, the empirical evidence is consistent with Schneider and 
Tornell's (2001) argument of asymmetric performance for firms depending on whether the firms benefit or are harmed by currency depreciations.

In addition to these models, our empirical evidence is in some respects consistent with the paper by Aghion et al. (2004), although their model does not explicitly deal with currency crises. In that model, the liberalization of a country's capital account leads to a relaxation of credit constraints for the firms in that country. This leads to initial increased investments and profitability for the firms in the tradable sector. Further investments lead to decreased profitability because of raising costs. This might lead to capital flight and a currency crisis. Empirically, the implications of Aghion et al. (2004) are similar to Bris and Koskinen (2002), although the economic mechanisms behind the results are different.

Also, a growing body of literature emphasizes corporate governance issues in currency crises. Johnson et al. (2000) show that lack of outside investor protection is positively related to the amount of depreciation in emerging markets. Mitton (2002) provides evidence that, during the Asian crisis, firms that had higher disclosure quality and higher outside ownership concentration also had better stock market performance. In addition, Lemmon and Lins (2003) show that a greater likelihood of outside shareholder expropriation led to lower stock market valuation during the Asian crisis. The approaches emphasizing corporate leverage and corporate governance can be viewed as complements. For example, to the extent that corporate governance problems lead to more reliance on debt financing at the expense of equity financing, the two approaches are consistent. However, in our crosssectional regression, we also control for corporate governance characteristics on the country level and find that our measure of exchange rate exposure still helps explain company-level leverage, while the corporate governance variables give inconsistent results.

The next section of the paper describes the data and its sources. In section II, we explain our approach to estimating exchange rate exposure. In section III, we study firm leverage and the relationship between leverage and exchange rate exposure. In section IV, we relate exchange rate exposure to several different measures of profitability. In section $\mathrm{V}$, we provide cross-sectional evidence on the determinants of capital structure. Section VI concludes the paper.

\section{Data and Sample Description}

Throughout the paper, we define a currency crisis as the event in which either a government or a central bank decides to let its currency float or administratively devalues it. We obtain information about currency crises that have occurred in the period 1985-2000. These are 
partly compiled in Kaminsky and Reinhart (1996). Additionally, Italy, the United Kingdom, and the countries that experienced the Asian crisis of 1997 are also included in the sample. When a country has suffered several crises in the period 1985-2000 (this is the case, for instance, for Brazil, Spain, and Turkey), the last one is considered exclusively. The final sample of crises includes 17 countries, and its description is in Table 1. Other major currency depreciations are not included in the final sample for a variety of reasons. For example, we do not include the Russian crisis of 1998 because of a lack of data on Russian firms. We also eliminate Bolivia, Chile, Colombia, Israel, Peru, and Uruguay because we lack stock price data before the crises. For some countries the most recent crisis has not been considered due to the unavailability of data after the crisis. ${ }^{3}$ Brazil, for instance, suffered its last crisis in 1999. In addition, we include three countries that did not suffer what we define as a currency crisis. However, these countries-Argentina, Hong Kong, and Japan-either suffered severe attacks on their currencies or experienced a modest currency depreciation initially. Argentina ${ }^{4}$ and Hong Kong ${ }^{5}$ had a currency board, and both countries experienced attacks on its currency, but neither country changed its exchange rate policy. Japan's exchange rate initially depreciated against the U.S. dollar ${ }^{6}$ but later fully recovered. We refer to these three countries as the no-crisis sample.

For each country in our total sample, Datastream provides a Global Market Index, that includes a varying number of firms per country. ${ }^{7}$ Datastream also provides accounting information regarding all the

3. We require 6 years of past information and 2 years of postcrisis data on stock prices for the firms available in the sample to perform the estimation.

4. Following the Mexican devaluation of December 1994, the Buenos Aires stock market witnessed the Merval blue-chip index sliding $17 \%$ in January 1995. At the same time, bonds fell sharply and short-term interest rates nearly tripled. The peso-dollar conversion rate was permitted to fall to 0.998 . Although Argentina had a currency board, the central bank was forced to take measures to increase the confidence in the peso and inject liquidity into the financial system: The central bank started converting pesos into dollars at par. Banks' reserve requirements on deposits were allowed in the currency of choice, eliminating central bank regulation of the denomination of reserves. Reserve requirements on dollar and peso deposit accounts were unified. The measures were well received by the Buenos Aires stock market. The blue-chip index closed up $10.34 \%$ the day after the announcement.

5. In October 1997, speculators pounded the Hong Kong dollar, hoping that the authorities would follow other Southeast Asian countries in allowing the currency to depreciate. The stock market lost $\$ 50$ billion in 3 days. Hong Kong overnight interest rates increased $300 \%$ on October 23. Speculators were shorting the Hong Kong dollar during this period.

6. The yen depreciated $7.37 \%$ in November 1997 , and it was at its 5e-year low in November 25. The Yamaichi Bank collapsed on November 22.

7. Included in each market index are 50 stocks from Brazil, 50 from Venezuela, 90 from Mexico, 50 from Finland, 50 from Norway, 120 from Spain, 70 from Sweden, 50 from Turkey, 550 from the United Kingdom, 160 from Italy, 50 from Indonesia, 100 from South Korea, 90 from Malaysia, 50 from the Phillippines, 100 from Singapore, 70 from Taiwan, 50 from Thailand. 


\begin{tabular}{|c|c|c|c|c|c|c|c|c|}
\hline \multirow[b]{2}{*}{ Country } & \multirow{2}{*}{$\begin{array}{l}\text { Crisis Month } \\
\quad(t=0)\end{array}$} & \multirow[b]{2}{*}{ Observs. } & \multirow{2}{*}{$\begin{array}{l}\text { Firms in } \\
\text { Main Exchange }\end{array}$} & \multirow{2}{*}{$\begin{array}{l}\text { Percent in } \\
\text { Sample }\end{array}$} & \multirow{2}{*}{$\begin{array}{l}\text { Market Return } \\
\quad(t=0)\end{array}$} & \multicolumn{2}{|c|}{ Currency Depreciation } & \multirow{2}{*}{$\begin{array}{l}\text { Median } \\
\text { Leverage } \\
(t=0)\end{array}$} \\
\hline & & & & & & $(t=0)$ & $(t=0)$ to $(t=+12)$ & \\
\hline Total & & 6,781 & 10,401 & $65.20 \%$ & $-3.39 \%$ & $-16.60 \%$ & $-23.52 \%$ & $35.89 \%$ \\
\hline Finland & September 1992 & 38 & 62 & $61.29 \%$ & $-15.74 \%$ & $-14.17 \%$ & $-21.40 \%$ & $47.04 \%$ \\
\hline Italy & September 1993 & 216 & 259 & $83.40 \%$ & $8.27 \%$ & $-3.24 \%$ & $-1.66 \%$ & $45.43 \%$ \\
\hline Norway & December 1992 & 52 & 123 & $42.28 \%$ & $15.72 \%$ & $-7.88 \%$ & $-7.99 \%$ & $42.78 \%$ \\
\hline Spain & May 1993 & 151 & 379 & $39.84 \%$ & $4.86 \%$ & $-8.64 \%$ & $-10.82 \%$ & $34.09 \%$ \\
\hline Sweden & November 1992 & 106 & 205 & $51.71 \%$ & $5.11 \%$ & $-19.84 \%$ & $-27.66 \%$ & $15.77 \%$ \\
\hline Turkey & March 1994 & 100 & 176 & $56.82 \%$ & $14.65 \%$ & $-55.05 \%$ & $-51.61 \%$ & $16.33 \%$ \\
\hline United Kingdom & September 1992 & 1,592 & 2,440 & $65.25 \%$ & $-3.38 \%$ & $-8.41 \%$ & $-19.79 \%$ & $27.45 \%$ \\
\hline Hong Kong & October 1997 & 366 & 658 & $55.62 \%$ & $-8.30 \%$ & $.16 \%$ & $-.15 \%$ & $26.96 \%$ \\
\hline Indonesia & August 1997 & 171 & 281 & $60.85 \%$ & $-8.35 \%$ & $-17.80 \%$ & $-79.48 \%$ & $40.00 \%$ \\
\hline Japan & November 1997 & 1740 & 1865 & $93.30 \%$ & $-19.50 \%$ & $-7.37 \%$ & $2.35 \%$ & $42.68 \%$ \\
\hline Malaysia & July 1997 & 353 & 703 & $50.21 \%$ & $-6.08 \%$ & $-9.42 \%$ & $-40.43 \%$ & $28.55 \%$ \\
\hline Philippines & July 1997 & 154 & 221 & $69.68 \%$ & $-4.68 \%$ & $-9.09 \%$ & $-32.43 \%$ & $16.95 \%$ \\
\hline Singapore & July 1997 & 197 & 334 & $58.98 \%$ & $-4.77 \%$ & $-5.05 \%$ & $-16.06 \%$ & $28.72 \%$ \\
\hline South Korea & November 1997 & 702 & 776 & $90.46 \%$ & $-17.25 \%$ & $-49.84 \%$ & $-25.01 \%$ & $55.22 \%$ \\
\hline Taiwan & October 1997 & 281 & 404 & $69.55 \%$ & $-7.65 \%$ & $-7.97 \%$ & $-14.04 \%$ & $23.87 \%$ \\
\hline Thailand & July 1997 & 412 & 431 & $95.59 \%$ & $29.46 \%$ & $-22.16 \%$ & $-28.36 \%$ & $45.83 \%$ \\
\hline Argentina & January 1995 & 13 & 149 & $8.72 \%$ & $-39.36 \%$ & $-.99 \%$ & $.07 \%$ & $33.23 \%$ \\
\hline Brazil & March 1995 & 76 & 570 & $13.33 \%$ & $-14.63 \%$ & $-8.69 \%$ & $-10.45 \%$ & $18.75 \%$ \\
\hline Mexico & December 1994 & 49 & 206 & $23.79 \%$ & $-4.54 \%$ & $-35.03 \%$ & $-55.52 \%$ & $40.00 \%$ \\
\hline Venezuela & December 1995 & 12 & 159 & $7.55 \%$ & $8.37 \%$ & $-41.52 \%$ & $-29.93 \%$ & $24.72 \%$ \\
\hline
\end{tabular}

NotE.- This table displays the number of firms in the sample, number of firms in the corresponding exchange, market return in the devaluation month, and currency depreciation in the crisis month and around the crisis month (attack month for the noncrisis sample); and median leverage at the time of the currency crises (currency attack for the noncrisis sample). The sample includes all firms with available information in Datastream for 17 countries that suffered a currency crises in the period 1985-2000, plus Argentina, Hong Kong, and Japan. Stock returns, exchange rates, market returns, and accounting variables are from Datastream. The number of firms in the main exchange is as of December of the corresponding crisis year, obtained from the International Federation of Stock Exchanges' website, at www.fibv.com/stats/ta11.xls. 
available firms in the corresponding market, for window of 5 years around the year of the currency crisis.

We are able to find information in Datastream for 6781 firms from the 20 countries we consider, 4662 firms in our crisis sample and 2119 firms in our control sample. Among those, 4376 firms are from Asia, ${ }^{8}$ 2255 from Europe, and 150 firms from Latin America. We compare the number of firms in our sample with the total number of firms in the stock exchange in the corresponding country as of December of the respective crisis year, as reported by the International Federation of Stock Exchanges. On average, our sample contains $65.20 \%$ of all the firms listed in a country's main stock exchange. This percentage is lower for Latin American countries, where currency depreciations happened earlier and, hence, the lack of data is a more severe problem.

In Table 1, we calculate the domestic stock market return during the month of the currency depreciation. On average, stock prices decline $3.39 \%$ during the crisis month. We also calculate the currency depreciation relative to the U.S. dollar, ${ }^{9}$ during both the crisis and month and the following year. The average currency depreciation in our sample amounts to $16.60 \%$ during the crisis month and $23.52 \%$ during the year (including the crisis month). The largest initial depreciation happened in Turkey (55.05\%) and the lowest in Italy (3.24\%) for the crisis sample. Indonesia suffered the biggest depreciation (79.48\%) in the 12 months following the crisis. Countries in the no-crisis sample had very stable currencies, especially if measured on a yearly basis. The median debt-to-value ratio (book values) for the total sample is $35.89 \%$, with Korea having the highest ratio (55.22\%), and Sweden the lowest (15.77\%). By regions, Asian countries display the highest debt levels, with a median leverage of $39.35 \%$. European countries have a $28.57 \%$ debt ratio and the median for Latin American is $23.99 \%$.

Table 2 describes the exchange rate regimes for the countries in our sample. Strictly speaking, only Brazil, Mexico, and the Philippines had fixed exchange rates prior to their currency devaluations. In addition to the member countries in the European Union, Finland, Norway, and Sweden maintained their exchange rates within a band with respect to the European currency unit (ECU). Other countries (South Korea, Indonesia, Singapore, and Taiwan) fixed their real exchange rates with respect to either the U.S. dollar or a basket of currencies. Malaysia and Venezuela allowed for fluctuations with respect to the dollar. Figure 1 shows that, although pegged to the dollar,

8. Pomerleano (1998), with a sample of firms that include Japan and Hong Kong, employs data from 734 companies.

9. Throughout the paper, exchange rates are calculated as units of dollars per domestic currency. 


\begin{tabular}{|c|c|}
\hline Argentina & Fixed peso-dollar exchange rate \\
\hline Brazil & Fixed against the dollar six months before the crisis. \\
\hline Spain & $\begin{array}{l}\text { The exchange rate is maintained within the margin of } \pm 15 \text { percent around the bilateral central rates against other participating } \\
\text { currencies, with the exception of Germany and the Netherlands, in which case the exchange rate is maintained within a margin of } \\
\pm 2.25 \text { percent. }\end{array}$ \\
\hline Finland & Unilaterally pegged to Ecu. \\
\hline Hong Kong & Currency Board since 1989 \\
\hline Japan & Flexible Exchange rates \\
\hline Indonesia & $\begin{array}{l}\text { Explicit real exchange rate targeting with the nominal rate falling from } 1900 \text { rupieh to the US } \$ \text { in } 1990 \text { to } 2400 \text { by the beginning of } \\
1997\end{array}$ \\
\hline South Korea & $\begin{array}{l}\text { The Korean won followed periods of fixity to the US \$ but had a more flexible exchange rate regime. The Won depreciated in nominal terms from } \\
1990 \text { until the beginning of } 1993 \text { (from } 700 \text { to almost } 800 \text { won per dollar). Next, it traded in a very narrow range of } 800 \text { to } 770 \text { won } \$ \$ \text { between } \\
\text { the beginning of } 1993 \text { and the middle of } 1996 \text {. Then, it started to depreciate by about } 10 \% \text { reaching a rate of } 884 \text { at the end of } 1996\end{array}$ \\
\hline Mexico & Fixed peso-dollar exchange rate \\
\hline Malaysia & A $10 \%$ range of 2.7 to 2.5 ringitt to the US\$ for most of the years between 1990 and the beginning of 1997 \\
\hline Norway & The krone was first pegged to the Ecu on October 19,1990 , within a margin of $+2.25 \%$ per cent from a fixed rate of $\mathrm{NKr} 7.9940$ per Ecu. \\
\hline Philippines & $\begin{array}{l}\text { The Peso fluctuated in a } 15 \% \text { range of } 28 \text { to } 24 \text { between } 1990 \text { and the beginning of } 1995 \text { but was practically fixed at a } 26.2 \text { rate to the US dollar from } \\
\text { the spring of } 1995 \text { until the beginning of } 1997\end{array}$ \\
\hline Sweden & Behaved as an ERM country, although not officially in the system. \\
\hline Singapore & The currency actually appreciated in nominal terms throughout the 1990 s going from a rate of 1.7 in 1990 to a rate of 1.4 by the end of 1996 . \\
\hline Italy & $\begin{array}{l}\text { The exchange rate is maintained within a margin of } \pm 15 \text { percent around the bilateral central rates against other participating currencies, with the } \\
\text { exception of Germany and the Netherlands, in which case the exchange rate is maintained within a margin of } \pm 2.25 \text { percent. }\end{array}$ \\
\hline Taiwan & Real exchange rate targeting allowing its currency to fall from a rate of 24 New Taiwan dollars per US\$ in 1990 to a rate of 27.8 by the end of 1996. \\
\hline Thailand & The Thai Bath was effectively fixed in a narrow 25.2 to 25.6 to the US\$ from 1990 until 1997 \\
\hline Turkey & Managed floating exchange rate. \\
\hline United Kingdom & $\begin{array}{l}\text { The exchange rate is maintained within a margin of } \pm 15 \text { percent around the bilateral central rates against other participating currencies, with the } \\
\text { exception of Germany and the Netherlands, in which case the exchange rate is maintained within a margin of } \pm 2.25 \text { percent. }\end{array}$ \\
\hline Jene & e exchange rate is maintained within margins of \pm 7.5 percent. \\
\hline
\end{tabular}

NoтE.-The Table describes the Exchange Rate Regimes of seventeen countries that have suffered currency crises since 1990, and three countries that have suffered severe currency attacks during the same period. The description corresponds to the regime prevailing one month prior to the last currency depreciation considered in Table 1.

SourCE.- Nouriel Roubini, "An Introduction to Open Economy Macroeconomics. Currency Crises and the Asian Crisis", in http://www.stern.nyu.edu/ nroubini/NOTES/ macro5.htm \#9, and Lexis-Nexis. 


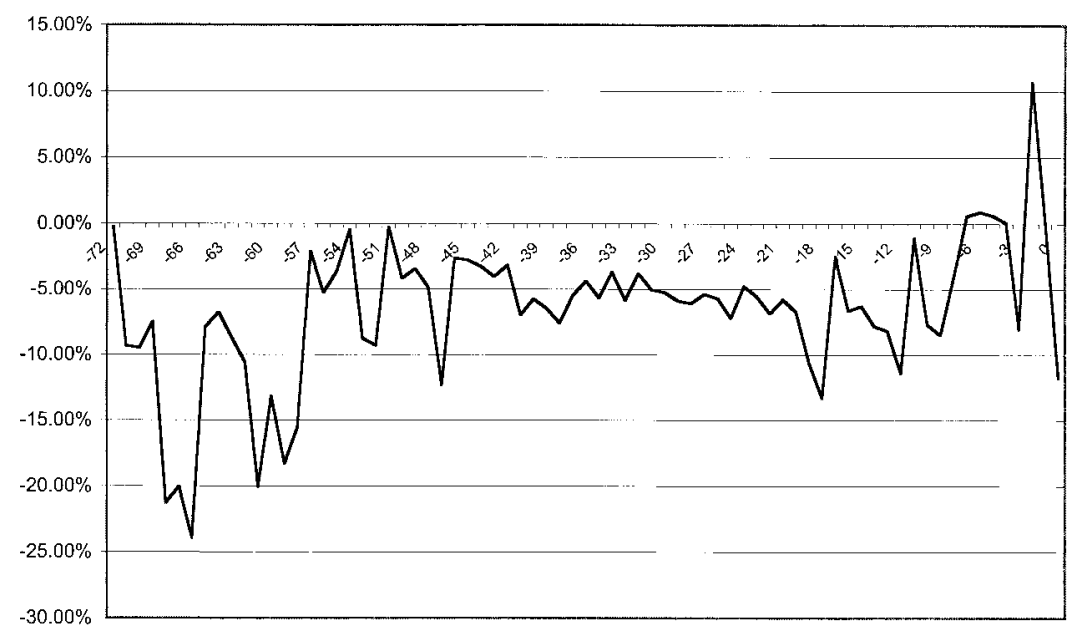

(a) Crisis Sample Latin America

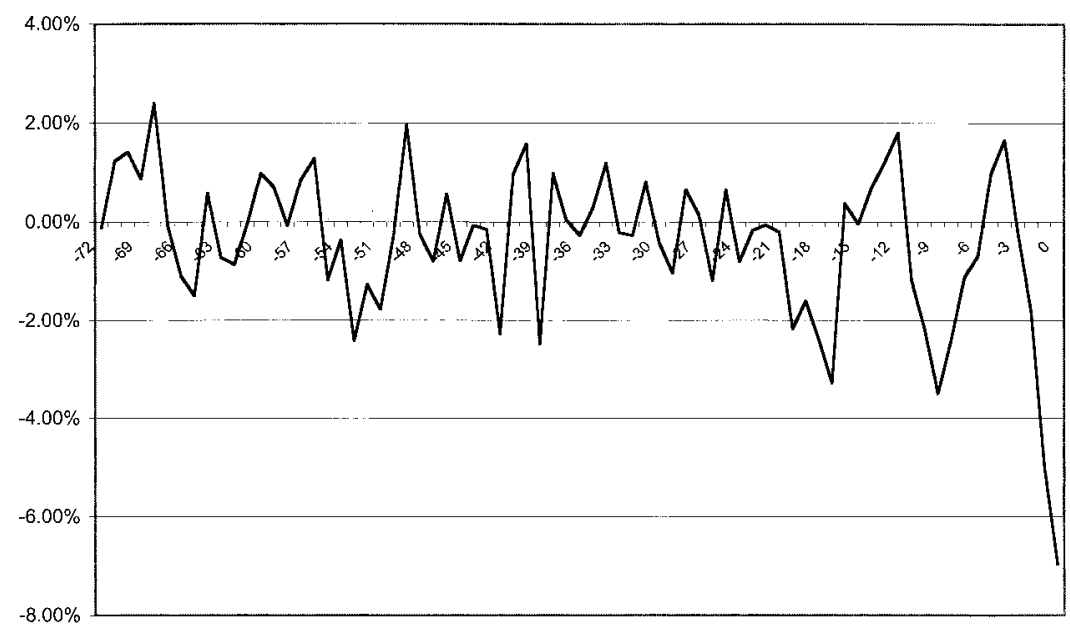

(b) Crisis Sample: Europe

FIG. 1.-Exchange Rate Changes before Currency Crises. The graph shows the average appreciation or depreciation of the nominal exchange rate U.S. dollar/domestic currency in the 72 months preceding the currency crises in (a), Latin America (Brazil, Mexico, and Venezuela), (b), Europe (Finland, Italy, Norway, Spain, Sweden, Turkey, and the United Kingdom), (c), Asia (Indonesia, Malaysia, the Philippines, Singapore, South Korea, Taiwan, and Thailand), and $(d)$, the no-crisis sample of countries with either floating rates or currency boards (Argentina, Hong Kong, and Japan) considered in the paper. 


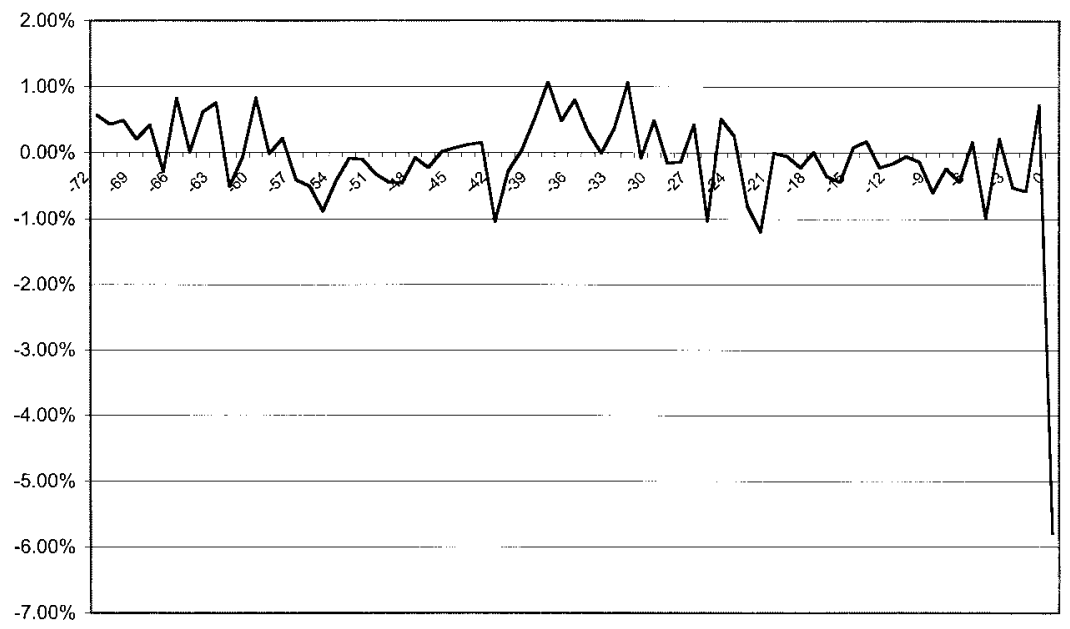

(c) Crisis Sample: Asia

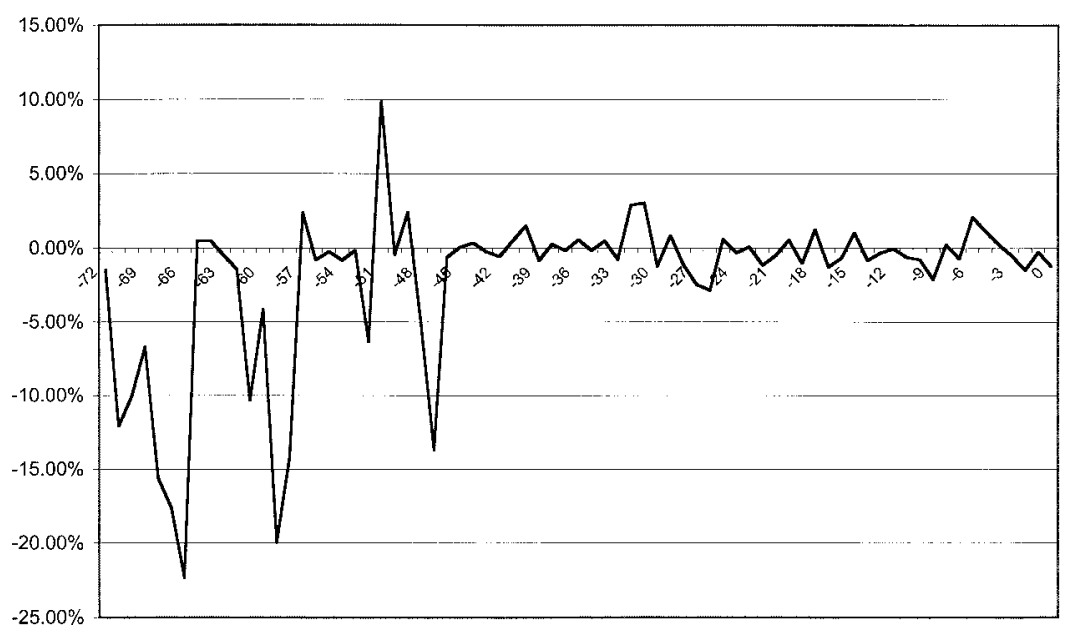

(d) No Crisis Sample

FIG. 1.-Continued.

Latin American currencies fluctuated the most before the crises. Brazil pegged the real only 6 months before its last devaluation, and Mexico suffered several crises before the ones we consider in this paper. Asian exchange rates were the least volatile in the last 6 years before a crisis (the standard deviation of the monthly change in exchange rates is $0.84 \%$ in Asia, $1.54 \%$ in Europe, and $5.52 \%$ in Latin America).

In the next section, we survey the literature on exchange rate exposure and propose a new methodology that allows us to differentiate firms depending on whether they benefit from or are harmed by 
currency depreciations. We regress the stock return of every firm on exchange rate changes and the component of the domestic market return orthogonal to the changes in the exchange rate.

\section{Exchange Rate Exposure}

For the past 20 years, financial researchers have paid a great deal of attention to how to measure a firm's exposure to exchange rate movements. The basic models can be grouped into two categories: accounting-based exposure and stock-price-based exposure. For our purposes, the accounting-based approach poses at least three problems. First of all, lack of data. The number of firms for which data on exports is available is quite limited in emerging markets. ${ }^{10}$ Second, foreign sales may not be an accurate proxy for exchange rate exposure, because of hedging and debt denominated in foreign currencies. Finally, a firm that operates only in the domestic market nonetheless may be exposed to exchange rate risk, if competitors are foreign firms that sell to the country where the domestic firm operates. ${ }^{11}$ Therefore, movements in the exchange rate affect the competitiveness of the domestic firm and its profits, Hence, in this paper we use a stockmarket-based measure of exchange rate exposure.

Among the studies that focus on stock price-based exposure, Jorion (1990, 1991), Bodnar and Gentry (1993), and Amihud (1994) regress a company's stock return on exchange rate changes and additional control variables such as a market portfolio return. ${ }^{12}$ Jorion (1991) uses a twofactor model, with the value-weighted stock market return as the first factor and the orthogonal component of innovations in a trade-weighted exchange rate as the second factor. The orthogonalization eliminates spurious pricing of the exchange rate factor because of a possible correlation between exchange rate and market return.

Finally, Bodnar and Wong (2000) suggest that the inclusion of a market portfolio increases the precision of the residual exposure estimates. However, if the market portfolio has a nonzero exposure, including a market portfolio as a regressor shifts the distribution of the residual exposure estimates with respect to the total exposure counterparts. Therefore, residual exposure estimates reflect the deviation of the

10. In their paper on the Asian crises of 1997, Allayannis, Brown, and Klapper (2003) are able to find data on exports for only the largest 50 companies in each country.

11. For example, shipbuilders in China argued for a devaluation of the renminbi in 1998, since Japanese and South Korean shipbuilders became more competitive as a result of the 1997 crises (Financial Times, July 6, 1998).

12. In the early studies of Dumas (1978), Adler and Dumas (1983), and Hodder (1982), exposure was measured by the regression coefficient of the real value of the firm on the exchange rate. Although these models are easy to implement, they find the percentage of firms with a significant exposure to exchange rate movements to be low. 
firm's exposure from the market's portfolio exposure. As most studies use a value-weighted portfolio, dominated by large firms with a more negative exposure to exchange rate movements, the residual exposure estimates suffer from a positive shift. The solution the authors suggest is the use of an equal-weight market portfolio to correct for the correlation between firm size and the sign of the exchange rate exposure.

\section{A. An Alternative Approach}

Our calculation of the exchange rate exposure is inspired by Jorion (1991). However, our procedure is exactly the opposite of Jorion's: In explaining individual companies' stock returns, we use as regressors the change in exchange rate and the component of market return orthogonal to the change in exchange rate. This methodology circumvents the critique made by Bodnar and Wong (2000). We measure exchange rate exposure in the absolute sense, not relative to the market as a whole. To avoid nonsynchronous movements in exchange rates and stock returns, we use monthly data.

First we estimate the following regression for each country in our sample:

$$
R_{m t}^{j}=\gamma_{o}^{j}+\gamma_{1}^{j} R_{x t}^{j}+v_{s t}^{j} \quad \text { for all } j=1, \ldots, 20
$$

where $R_{m t}^{j}$ is the market return, and $R_{x t}^{j}$ is the change in the exchange rate in country $j$. We estimate the $\gamma$ coefficients using monthly data from month $t=-72$ to month $t=-37$ relative to the currency depreciation month. ${ }^{13}$ Next, we calculate $F_{m t}^{j}=R_{m t}^{j}-\left(\hat{\gamma}_{o}^{j}+\hat{\gamma}_{1}^{j} R_{x t}^{j}\right)$ from the previous regression and use the estimated orthogonal component of market return in the regression:

$$
R_{i j t}=\delta_{i}+\beta_{i}^{x} R_{x t}^{j}+\beta_{i}^{m} F_{m t}^{j}+\epsilon_{i j t}
$$

where $R_{i j}$ is the stock return of firm $i$ in country $j, R_{x}^{j}$ is the monthly change in the exchange rate in country $j$, and $F_{m}^{j}$ is the estimated orthogonal component for market $j$. Note that, if the $\hat{\gamma}_{1}$ coefficients are not significantly different from zero, the orthogonalization induces an error in variables problem and the variance of $\hat{\beta}_{i}^{x}$ is inflated. Therefore, we calculate $F_{m t}$ with $\hat{\gamma}_{1}=0$ when its significance level ${ }^{14}$ is higher than $10 \%$.

13. Calculating market-based exchange rate exposure can be problematic for countries with currency boards. Argentina, for instance, has had a currency board since 1991. We use data on Argentinian companies from 1989 to 1992 to calculate exchange rate exposures (Argentina crises happened in 1995), so firm sensitivities are calculated with pre-currency board data. Hong Kong pegged its currency to the U.S. dollar in 1983. However, the parity has changed constantly since then.

14. The results in the paper are not sensitive to the choice of the minimum significance level. In fact, when we limit ourselves to significance levels of $1 \%$ of better, our ERB estimates arise from regressing stock returns on exchange rate changes directly (see table 3 ). 
The estimated $\hat{\beta}_{i}^{x}$ values are, as stated, measures of firm $i$ 's exposure to exchange rate risk (the exchange rate beta or ERB). ${ }^{15}$

Exchange rate exposure can be also affected by changes in leverage. A firm that borrows in a foreign currency is more likely to display a positive ERB. Thus, the ERB becomes endogenous. To avoid this problem, the estimation window for the ERB coefficients ends 3 years prior to the corresponding currency crisis. The changes in leverage we analyze in the paper, ranging from year $t=-3$ to year $t=+2$ relative to the crisis year, are therefore exogenous to past currency exposures.

Some of the countries where we calculate exchange rate exposures had fixed exchange rate regimes during the estimation period. Intuitively, one expects exchange rate betas to be insignificant because of the invariability of exchange rates. However, it is worth noting that, as Figure 1 shows, the nominal exchange rates in these countries fluctuated considerably. In Europe, currencies were allowed to fluctuate within a band. In Asia, some of the pegs were real; in other countries the currency was pegged to the yen and not the dollar. Finally, in still other countries like Taiwan, the currency fluctuated, also within a band. This is clear evidence that the exchange rate regimes did not eliminate firms' currency risk.

In Table 3, we show for each country the average and median exchange rate betas and the market betas ${ }^{16}$ as well as each individual market exposure coefficient to exchange rate movements, following the methodology outlined earlier. The average exchange rate beta is the size-weighted average of the exchange rate betas calculated for the firms in a particular country. The market exposure is, for every country, the estimate of $\gamma_{1}$ in regression (1).

Only in eight countries, is the country exposure (the $\gamma_{1}$ coefficient) significant at the $10 \%$ level or better. All European countries, except Turkey, have a negative value for $\gamma_{1}$, whereas in Asia, countries have both negative and positive exposures. In Thailand, for instance, the country exposure is -5.659 (significant at the $5 \%$ level). Indonesia, at the other extreme, displays a country exposure of 6.029 (also significant at the 5\% level). In our control sample, Argentina has a negative country exposure of -0.760 (significant at the $5 \%$ level).

We expect exporting firms to display a negative exchange rate beta, while domestic firms should have a positive exposure. Seoul Foods, for instance, a South Korean firm that manufactures bread and snack foods

15. In this paper, we report only the results we get using all of our observations. As a robustness check, we also calculated all the results using only the observations whose estimates of the exchange rate exposure are significant at the $10 \%$ level or lower. None of the qualitative results change. These results are available on request.

16. If the estimates for country exposure $\widehat{\gamma}_{1}$ are significant, then we report the orthogonalized market betas; otherwise, ordinary market betas are reported. 


\begin{tabular}{|c|c|c|c|c|c|c|c|c|c|c|c|}
\hline \multirow[b]{2}{*}{ Country } & \multirow[b]{2}{*}{$\mathrm{N}$} & \multicolumn{2}{|c|}{$\begin{array}{l}\text { Exchange } \\
\text { Rate Beta }\end{array}$} & \multicolumn{2}{|c|}{$\begin{array}{l}\text { Market } \\
\text { Beta }\end{array}$} & \multicolumn{2}{|c|}{$\begin{array}{l}\text { Country } \\
\text { Exposure }\end{array}$} & \multicolumn{2}{|c|}{$\begin{array}{c}\text { Negative Exchange } \\
\text { Rate Beta }\end{array}$} & \multicolumn{2}{|c|}{$\begin{array}{c}\text { Positive Exchange } \\
\text { Rate Beta }\end{array}$} \\
\hline & & Mean & Median & Mean & Median & Estimate & p-value & $\%$ Firms & $\%$ Significant & $\%$ Firms & $\%$ Significant \\
\hline Total & 6,781 & 0.21772 & -0.10233 & 0.84968 & 0.7973 & $-0.022^{* * *}$ & $(0.0087)$ & $64.73 \%$ & $9.73 \%$ & $35.27 \%$ & $6.88 \%$ \\
\hline Finland & 38 & -0.349 & -0.147 & 0.360 & 0.643 & -0.388 & $(0.2031)$ & $74.42 \%$ & $9.30 \%$ & $25.58 \%$ & $0.00 \%$ \\
\hline Italy & 216 & -0.341 & -0.277 & 0.581 & 0.570 & -0.132 & $(0.6555)$ & $69.09 \%$ & $17.27 \%$ & $30.91 \%$ & $0.45 \%$ \\
\hline Norway & 52 & -0.228 & -0.081 & 0.542 & 0.692 & -0.278 & $(0.6002)$ & $67.74 \%$ & $6.45 \%$ & $32.26 \%$ & $0.00 \%$ \\
\hline Spain & 151 & 0.183 & 0.195 & 0.771 & 0.806 & -0.340 & $(0.2520)$ & $68.07 \%$ & $7.83 \%$ & $31.93 \%$ & $0.60 \%$ \\
\hline Sweden & 106 & -0.817 & -1.106 & 0.679 & 0.787 & $-1.240^{* *}$ & $(0.0239)$ & $79.34 \%$ & $24.79 \%$ & $20.66 \%$ & $0.83 \%$ \\
\hline Turkey & 100 & 2.952 & 3.234 & 1.212 & 1.071 & $2.957^{* *}$ & $(0.0348)$ & $16.13 \%$ & $3.23 \%$ & $83.87 \%$ & $3.23 \%$ \\
\hline United Kingdom & 1,592 & 0.080 & 0.084 & 0.911 & 0.977 & $-0.507^{*}$ & $(0.0916)$ & $83.26 \%$ & $8.37 \%$ & $16.74 \%$ & $0.18 \%$ \\
\hline Hong Kong & 366 & 0.570 & 0.422 & 0.626 & 0.614 & 7.307 & $(0.4639)$ & $43.48 \%$ & $2.56 \%$ & $56.52 \%$ & $1.79 \%$ \\
\hline Indonesia & 171 & 2.814 & 2.730 & 0.671 & 0.639 & $6.029^{* *}$ & $(0.0139)$ & $25.98 \%$ & $0.98 \%$ & $74.02 \%$ & $15.69 \%$ \\
\hline Japan & 1,740 & -0.011 & -0.037 & 1.072 & 1.055 & -0.119 & $(0.6314)$ & $66.24 \%$ & $17.41 \%$ & $33.76 \%$ & $22.54 \%$ \\
\hline Malaysia & 353 & -1.354 & -1.053 & 1.302 & 1.277 & 0.681 & $(0.3142)$ & $44.53 \%$ & $10.94 \%$ & $55.47 \%$ & $2.08 \%$ \\
\hline Philippines & 154 & 0.048 & 0.000 & 0.434 & 0.330 & 0.227 & $(0.6908)$ & $38.42 \%$ & $3.39 \%$ & $61.58 \%$ & $0.56 \%$ \\
\hline Singapore & 197 & -1.151 & -1.029 & 0.966 & 1.002 & -0.584 & $(0.4458)$ & $82.88 \%$ & $7.21 \%$ & $17.12 \%$ & $0.90 \%$ \\
\hline South Korea & 702 & 0.208 & 0.000 & 0.446 & 0.376 & 1.089 & $(0.6180)$ & $79.74 \%$ & $2.12 \%$ & $20.26 \%$ & $0.40 \%$ \\
\hline Taiwan & 281 & -0.094 & -0.182 & 0.586 & 0.585 & 1.593 & $(0.1941)$ & $67.14 \%$ & $0.31 \%$ & $22.86 \%$ & $4.04 \%$ \\
\hline Thailand & 412 & -0.885 & -0.288 & 0.375 & 0.394 & $-5.659^{* *}$ & $(0.0233)$ & $61.57 \%$ & $9.84 \%$ & $38.43 \%$ & $1.82 \%$ \\
\hline Argentina & 13 & -1.483 & -1.026 & 0.950 & 0.985 & $-0.760^{* *}$ & $(0.0185)$ & $56.52 \%$ & $47.83 \%$ & $43.48 \%$ & $0.00 \%$ \\
\hline Brazil & 76 & 0.247 & 0.000 & 0.364 & 0.253 & $-1.855^{* *}$ & $(0.0202)$ & $44.64 \%$ & $3.57 \%$ & $55.36 \%$ & $0.89 \%$ \\
\hline Mexico & 49 & -2.078 & -1.999 & 0.027 & 0.454 & $-4.443^{* *}$ & $(0.0480)$ & $76.71 \%$ & $8.22 \%$ & $23.29 \%$ & $0.00 \%$ \\
\hline Venezuela & 12 & 0.227 & 0.291 & 0.935 & 0.816 & 1.806 & $(0.1905)$ & $0.00 \%$ & $0.00 \%$ & $100.00 \%$ & $0.00 \%$ \\
\hline
\end{tabular}

NoтE.-Number of firms in the sample per country, size-weighted average firm exchange rate beta, and average firm market beta. Size is as of the year of the currency crisis 'Country Exposure' is the coefficient of a regression of the country's market return on exchange rate changes. Stock returns, Exchange rates, Market Returns and accounting variables are from Datastream.

$*$ and $* *$ indicate that the coefficient is significantly different from zero at the 0.1 and 0.05 levels or better, respectively. 
(arguably a nonexporting firm) has a beta of 1.783 . An exporting firm such as Shin Corporation, ${ }^{17}$ from Taiwan, has a beta of -4.241 . The results for the average market betas are consistent with Bodnar and Wong (2000), since we find markets to be exposed to currency movements.

Therefore, in the absence of data on the structure of the balance sheet for each firm, we are able to classify every firm in the sample into two categories, depending on its exposure to exchange rate movements: firms that benefit from currency depreciations and firms that suffer from depreciations. It is worth noting that exporting firms may have an insignificant exchange rate beta if they hedge their currency exposure or have borrowed in foreign currencies. ${ }^{18}$

We rank firms in a particular country by their exchange rate beta. Firms are not comparable in terms of exchange rate exposure across countries. Therefore, we rank each firm with respect to the other companies in the same country by splitting the sample between firms with negative and positive exchange-rate betas.

In the next section, we analyze the different effects of the currency depreciation on firms, depending on whether the firm has negative or positive exposure to currency movements.

\section{Firm Leverage}

In this section, we report debt-to-value ratios, as a measure of leverage, for all the firms in our sample. ${ }^{19}$ The debt-to-value ratio is analyzed for the 3 years preceding the currency devaluation, as well as for 2 years after the devaluation. For each firm, we gather data on its total debt-tovalue ratio as well as on the percentage of short-term debt to total debt from Datastream. Both ratios are in book values. We use book values primarily because using market values yields spurious results. For example, a decline in stock prices before a currency depreciation implies an increase in debt-to-value ratios with no increase in the amount of debt, if market values are used.

First, we report firm-level debt-to-value ratios country by country and on a regional level. The results are shown in table 4 . For the overall

17. Shiang Shin Corporation, located in Taiwan, is engaged in the manufacturing and exporting of nitrile gloves, latex surgical gloves, latex examination gloves, vinyl examination gloves and other disposable medical products. Its main markets are in the United States, Europe, Australia, Japan, and Central and South America.

18. Allayannis and Ihrig (2001) and Dominguez and Tesar (2001) provide evidence, that estimates of exchange rate exposure are time-varying and often change signs. In our context, classification of a firm to a wrong exchange rate exposure group would be a conservative mistake.

19. Throughout the paper, we consider the debt-to-value ratio as the object of study. The results do not change qualitatively when we use the debt-to-equity ratio instead. 


\begin{tabular}{|c|c|c|c|c|c|c|c|c|c|c|c|}
\hline Country & $N$ & $t=-3$ & $t=-2$ & $t=-1$ & $t=0$ & $t=+1$ & $t=+2$ & $\begin{array}{l}\text { Change from } \\
(t=-3) \text { to } \\
(t=-1)\end{array}$ & $p$ Value & $\begin{array}{l}\text { Change from } \\
\qquad \begin{array}{c}(t=0) \text { to } \\
(t=+2)\end{array}\end{array}$ & $p$ Value \\
\hline Total sample & 6,781 & $33.71 \%$ & $34.02 \%$ & $35.56 \%$ & $35.86 \%$ & $38.87 \%$ & $37.50 \%$ & $1.91 \% * * *$ & $(<.0001)$ & $3.73 \% * * *$ & $(<.0001)$ \\
\hline Europe & 2,255 & $24.78 \%$ & $28.08 \%$ & $28.88 \%$ & $28.57 \%$ & $28.52 \%$ & $27.10 \%$ & $12.78 \% * * *$ & $(<.0001)$ & $-2.66 \%$ & $(.4820)$ \\
\hline Finland & 38 & $46.65 \%$ & $51.08 \%$ & $46.51 \%$ & $47.04 \%$ & $53.71 \%$ & $46.56 \%$ & $17.96 \%$ & $(.1602)$ & $2.08 \%$ & $(.5016)$ \\
\hline Italy & 216 & $38.34 \%$ & $43.59 \%$ & $41.16 \%$ & $45.43 \%$ & $50.28 \%$ & $43.98 \%$ & $2.32 \%$ & $(.4762)$ & $4.90 \%$ & $(.2315)$ \\
\hline Norway & 52 & $43.92 \%$ & $34.43 \%$ & $34.19 \%$ & $42.78 \%$ & $50.95 \%$ & $43.91 \%$ & $-4.36 \%$ & $(.4903)$ & $5.61 \%$ & $(.4892)$ \\
\hline Spain & 151 & $25.80 \%$ & $31.37 \%$ & $30.39 \%$ & $34.09 \%$ & $29.50 \%$ & $31.74 \%$ & $2.35 \%$ & $(.3509)$ & $-4.72 \%$ & $(.9905)$ \\
\hline Sweden & 106 & $12.21 \%$ & $13.50 \%$ & $15.51 \%$ & $15.77 \%$ & $14.43 \%$ & $17.94 \%$ & $-6.08 \%$ & $(.5353)$ & $7.83 \%$ & $(.6714)$ \\
\hline Turkey & 100 & $19.63 \%$ & $29.63 \%$ & $23.42 \%$ & $16.33 \%$ & $29.34 \%$ & $19.20 \%$ & $25.93 \%$ & $(.2413)$ & $-5.47 \%$ & $(.4455)$ \\
\hline United Kingdom & 1,592 & $24.20 \%$ & $27.65 \%$ & $28.60 \%$ & $27.45 \%$ & $27.42 \%$ & $26.09 \%$ & $14.38 \% * * *$ & $(<.0001)$ & $-3.01 \%$ & $(0.8201)$ \\
\hline Asia & 4,376 & $39.47 \%$ & $38.47 \%$ & $39.07 \%$ & $39.35 \%$ & $44.35 \%$ & $43.65 \%$ & $0.42 \% * * *$ & $(<.0001)$ & $4.83 \% * * *$ & $(<.0001)$ \\
\hline Hong Kong & 366 & $21.51 \%$ & $25.63 \%$ & $28.80 \%$ & $26.96 \%$ & $27.79 \%$ & $27.84 \%$ & $22.40 \% * * *$ & $(<.0001)$ & $-1.43 \% * *$ & $(.0193)$ \\
\hline Indonesia & 171 & $45.00 \%$ & $40.00 \%$ & $40.00 \%$ & $40.00 \%$ & $50.00 \%$ & $50.00 \%$ & $-11.11 \%$ & $(.1218)$ & $25.00 \% * * *$ & $(<.0001)$ \\
\hline Japan & 1,740 & $45.38 \%$ & $45.12 \%$ & $43.99 \%$ & $42.68 \%$ & $41.84 \%$ & $43.40 \%$ & $-1.16 \% * * *$ & $(.0001)$ & $.73 \%$ & $(.1190)$ \\
\hline Malaysia & 154 & $21.50 \%$ & $18.16 \%$ & $23.36 \%$ & $28.55 \%$ & $37.41 \%$ & $37.74 \%$ & $5.54 \% * *$ & $(.0156)$ & $39.99 \% * * *$ & $(<.0001)$ \\
\hline Philippines & 197 & $8.60 \%$ & $8.32 \%$ & $14.99 \%$ & $16.95 \%$ & $24.99 \%$ & $26.38 \%$ & $12.33 \%$ & $(.3846)$ & $29.69 \% * * *$ & $(.0001)$ \\
\hline Singapore & 702 & $20.99 \%$ & $20.80 \%$ & $24.69 \%$ & $28.72 \%$ & $33.40 \%$ & $32.93 \%$ & $18.47 \% * * *$ & $(<.0001)$ & $10.92 \% * * *$ & $(.0006)$ \\
\hline South Korea & 353 & $53.45 \%$ & $52.22 \%$ & $52.88 \%$ & $55.22 \%$ & $61.91 \%$ & $53.52 \%$ & $3.22 \% * * *$ & $(<.0001)$ & $2.51 \% * * *$ & $(.0005)$ \\
\hline Taiwan & 281 & $28.54 \%$ & $22.08 \%$ & $22.25 \%$ & $23.87 \%$ & $27.80 \%$ & $29.73 \%$ & $-5.92 \%$ & (.6639) & $24.51 \% * * *$ & $(<.0001)$ \\
\hline Thailand & 412 & $39.30 \%$ & $40.29 \%$ & $46.29 \%$ & $45.83 \%$ & $61.48 \%$ & $54.99 \%$ & $8.08 \% * * *$ & $(<.0001)$ & $15.35 \% * * *$ & $(.0004)$ \\
\hline \multicolumn{12}{|l|}{ Latin } \\
\hline America & 150 & $18.30 \%$ & $18.25 \%$ & $22.19 \%$ & $23.99 \%$ & $28.34 \%$ & $29.79 \%$ & $7.16 \% *$ & $(.0586)$ & $21.06 \% * * *$ & $(.0002)$ \\
\hline
\end{tabular}


TABLE 4 (Continued)

\begin{tabular}{|c|c|c|c|c|c|c|c|c|c|c|c|}
\hline Country & $N$ & $t=-3$ & $t=-2$ & $t=-1$ & $t=0$ & $t=+1$ & $t=+2$ & $\begin{array}{l}\text { Change from } \\
(t=-3) \text { to } \\
(t=-1)\end{array}$ & $p$ Value & $\begin{array}{l}\text { Change from } \\
\qquad \begin{array}{c}(t=0) \text { to } \\
(t=+2)\end{array}\end{array}$ & $p$ Value \\
\hline Argentina & 13 & $18.30 \%$ & $24.97 \%$ & $34.55 \%$ & $33.23 \%$ & $38.33 \%$ & $32.42 \%$ & $36.70 \% *$ & $(.0938)$ & $18.47 \%$ & $(.2163)$ \\
\hline Brazil & 76 & $21.42 \%$ & $18.50 \%$ & $20.92 \%$ & $18.75 \%$ & $33.19 \%$ & $35.68 \%$ & $-8.67 \%$ & $(.8125)$ & $95.55 \% * * *$ & $(.0039)$ \\
\hline Mexico & 49 & $32.58 \%$ & $33.88 \%$ & $38.27 \%$ & $40.00 \%$ & $54.74 \%$ & $49.87 \%$ & $15.75 \% * *$ & $(.0269)$ & $27.34 \% * * *$ & $(<.0001)$ \\
\hline Venezuela & 12 & $24.13 \%$ & $21.43 \%$ & $21.06 \%$ & $24.72 \%$ & $21.67 \%$ & $23.36 \%$ & $1.01 \%$ & $(.8438)$ & $8.79 \%$ & $(0.3750)$ \\
\hline $\begin{array}{l}\text { Crisis } \\
\text { sample } \\
\text { No-crisis }\end{array}$ & 4,662 & $30.13 \%$ & $31.85 \%$ & $33.22 \%$ & $34.34 \%$ & $38.88 \%$ & $36.24 \%$ & $4.43 \% * * *$ & $(<.0001)$ & $8.35 \% * * *$ & $(<.0001)$ \\
\hline $\begin{array}{l}\text { sample } \\
\text { Difference }\end{array}$ & 2,119 & $40.32 \%$ & $40.25 \%$ & $40.47 \%$ & $38.40 \%$ & $38.41 \%$ & $39.64 \%$ & $.01 \%$ & $(.4082)$ & $.72 \% *$ & $(.0956)$ \\
\hline $\begin{array}{l}\text { ( } p \text { value }) \\
\text { Non-Asian }\end{array}$ & & $(<.0001)$ & $(<.0001)$ & $(<.0001)$ & $(<.0001)$ & $(.3826)$ & $(.0002)$ & $(<.0001)$ & & $(<.0001)$ & \\
\hline $\begin{array}{l}\text { countries } \\
\text { Difference } \\
\text { Asian-Non- } \\
\text { Asian } \\
\text { ( } p \text { value })\end{array}$ & 2,405 & $24.47 \%$ & $27.50 \%$ & $28.60 \%$ & $28.20 \%$ & $28.52 \%$ & $27.33 \%$ & $12.53 \% * * *$ & $(.0000)$ & $-1.19 \% * * *$ & $(.0875)$ \\
\hline
\end{tabular}

NoтE.-This table displays the median Debt to Value Ratio by country. The debt-to-value ratio is calculated dividing total debt by the sum of total debt plus the book value of equity. In the last panel, we report p-values corresponding to a two-tailed Wilcoxon test of difference in medians. Stock returns, Exchange rates, Market Returns and accounting variables are from Datastream.

$*, * *$ and $* * *$ indicate that the coefficient is significantly different from zero at the $0.1,0.05$ and 0.01 levels or better, respectively. 
sample, the median increase in leverage is $1.91 \%$ in the 2 years preceding a crisis (significant at the 1\% level). The increase is $12.78 \%$ in Europe (significant at the $1 \%$ level), $0.42 \%$ in Asia (also significant at the $1 \%$ level), and $7.16 \%$ in Latin America (significant at the $10 \%$ level). For the countries with currency crises, the increase is a significant $4.43 \%$, but for the control sample, there is no increase in leverage prior to the currency attack. In levels, Asia as a region has the highest leverage throughout. At the country level, in the year of a crisis, we document high leverage in Europe for Finland, Italy, and Norway (all above 40\%); in Asia for Indonesia, Japan, Korea, and Thailand (ranging from $40 \%$ to over 51\%); and in Latin America for Mexico $(40 \%)$.

In the 2 years after a crisis, the debt ratio increases by $3.73 \%$ for the overall sample (significant at the 1\% level). For the crisis sample, the increase is $8.35 \%$ (significant at the $1 \%$ level), but for the control sample, the increase is only $0.72 \%$ (significant at the $10 \%$ level). In the postcrisis period, we document markedly different developments depending on the region. In Europe, there is not much change in the leverage level after the crisis. Asia and Latin America both exhibit a significant increase in debt-to-value ratios. For Asia, the increase in leverage is consistent throughout all the countries, except for Hong Kong and Japan, both of which belong to our control sample. Based on changes in leverage, the crises in Europe and Asia are different: increases in leverage before the crises for both regions but continuing increases in Asia even after the crisis, while in Europe there is no change for the postcrisis period. If we group all the non-Asian countries together, there is even a significant decline in leverage after the crises $(-1.19 \%)$.

After studying the changes in leverage on a firm level, we sort firms into two groups based on their exchange rate exposure. Since in Aghion et al. (2001) and Bris and Koskinen (2002) the effect of depreciation on firms' financial distress problems is the opposite and Schneider and Tornell (2001) predict different patterns for firms in the tradable and nontradable sectors, it is important to establish what kind of firms increase their leverage prior to a currency crisis and what happens to different firms and their leverage after a crisis.

The results are shown in table 5 on a regional level for companies sorted into two groups based on their exchange rate exposure. For our crisis sample, we find that firms that benefit from a currency depreciation (those with negative exchange rate beta) increase their debt-tovalue ratios $7.35 \%$ in median (significant at the 1\% level) in the 2-year period that precedes a devaluation, while firms that suffer from a depreciation increase leverage by $1.59 \%$ (significant at the $1 \%$ level). The difference between negative- and positive-exposure firms is also significant at the $1 \%$ level. Negative-exchange-rate-beta firms increase 
TABLE 5 Debt-to-Value Ratio at the Region Level, by Exchange Rate Beta

\begin{tabular}{|c|c|c|c|c|c|c|c|c|c|c|c|c|}
\hline \multirow[b]{2}{*}{ Region } & \multirow{2}{*}{$\begin{array}{l}\text { Exchange } \\
\text { Rate Beta }\end{array}$} & \multirow[b]{2}{*}{$N$} & \multirow[b]{2}{*}{$t=-3$} & \multirow[b]{2}{*}{$t=-2$} & \multirow[b]{2}{*}{$t=-1$} & \multirow[b]{2}{*}{$t=0$} & \multirow[b]{2}{*}{$t=+1$} & \multirow[b]{2}{*}{$t=+2$} & \multicolumn{2}{|c|}{$\begin{array}{c}\text { From } t=-3 \text { to } \\
\qquad t=-1\end{array}$} & \multicolumn{2}{|c|}{$\begin{array}{l}\text { From } t=0 \text { to } \\
\quad t=+2\end{array}$} \\
\hline & & & & & & & & & Change & $p$ Value & Change & $p$ Value \\
\hline \multicolumn{13}{|c|}{ Crisis vs. No-Crisis Countries } \\
\hline \multicolumn{13}{|l|}{ Crisis sample: } \\
\hline \multirow[t]{2}{*}{ Total } & Negative & 3,138 & $29.46 \%$ & $31.93 \%$ & $34.09 \%$ & $36.02 \%$ & $38.50 \%$ & $36.64 \%$ & $7.35 \% * * *$ & $(<.0001)$ & $2.87 \% * * *$ & $(<.0001)$ \\
\hline & Positive & 1,524 & $\begin{array}{l}30.91 \% \\
(.2488)\end{array}$ & $\begin{array}{l}31.80 \% \\
\quad(.2616)\end{array}$ & $\begin{array}{l}32.35 \% \\
(.0044)\end{array}$ & $\begin{array}{l}33.10 \% \\
(.0003)\end{array}$ & $\begin{array}{l}39.16 \% \\
(.3975)\end{array}$ & $\begin{array}{l}35.50 \% \\
(.5224)\end{array}$ & $\begin{array}{l}1.59 \% * * * \\
(.0013)\end{array}$ & $(<.0001)$ & $\begin{array}{c}14.97 \% * * * \\
(.0001)\end{array}$ & $(<.0001)$ \\
\hline \multicolumn{13}{|l|}{ Crisis sample: } \\
\hline \multirow[t]{2}{*}{ Europe } & Negative & 1,874 & $25.65 \%$ & $29.08 \%$ & $29.68 \%$ & $29.20 \%$ & $29.30 \%$ & $27.93 \%$ & $13.66 \% *$ & $(.0991)$ & $-3.96 \% * * *$ & $(.0090)$ \\
\hline & Positive & 381 & $\begin{array}{l}21.61 \% \\
\quad(.0018)\end{array}$ & $\begin{array}{l}21.23 \% \\
\quad(.1068)\end{array}$ & $\begin{array}{l}23.54 \% \\
(.3492)\end{array}$ & $\begin{array}{l}23.00 \% \\
(.2244)\end{array}$ & $\begin{array}{r}26.69 \% \\
(.0122)\end{array}$ & $\begin{array}{l}25.11 \% \\
\quad(.0063)\end{array}$ & $\begin{array}{r}-1.86 \% \\
\quad(.6715)\end{array}$ & $(.6794)$ & $\begin{array}{c}2.06 \% * \\
(.7114)\end{array}$ & $(.0967)$ \\
\hline \multicolumn{13}{|l|}{ Crisis sample: } \\
\hline \multirow[t]{2}{*}{ Asia } & Negative & 1,255 & $42.08 \%$ & $42.01 \%$ & $46.52 \%$ & $48.69 \%$ & $51.72 \%$ & $50.00 \%$ & $5.69 \% * * *$ & $(<.0001)$ & $6.13 \% * * *$ & $(<.0001)$ \\
\hline & Positive & 1,015 & $\begin{array}{r}32.82 \% \\
(.3842)\end{array}$ & $\begin{array}{l}27.95 \% \\
(.1535)\end{array}$ & $\begin{array}{l}29.59 \% \\
\quad(.0033)\end{array}$ & $\begin{array}{l}32.78 \% \\
(.0002)\end{array}$ & $\begin{array}{l}45.52 \% \\
(.0033)\end{array}$ & $\begin{array}{l}46.50 \% \\
\quad(.2774)\end{array}$ & $\begin{array}{l}-3.92 \% \\
(<.0001)\end{array}$ & $(.5569)$ & $\begin{array}{l}25.00 \% * * * \\
(<.0001)\end{array}$ & $(<.0001)$ \\
\hline \multicolumn{13}{|l|}{ Crisis sample: } \\
\hline \multirow[t]{2}{*}{ Latin America } & Negative & 94 & $17.83 \%$ & $20.56 \%$ & $23.02 \%$ & $27.03 \%$ & $31.54 \%$ & $31.22 \%$ & $13.46 \% * * *$ & $(<.0001)$ & $25.65 \%$ & $(.2997)$ \\
\hline & Positive & 43 & $\begin{array}{r}18.96 \% \\
(.6268)\end{array}$ & $\begin{array}{r}17.58 \% \\
(.7359)\end{array}$ & $\begin{array}{l}17.94 \% \\
(.6342)\end{array}$ & $\begin{array}{r}16.41 \% \\
(.9015)\end{array}$ & $\begin{array}{r}21.38 \% \\
\quad(.8411)\end{array}$ & $\begin{array}{r}24.32 \% \\
(.5630)\end{array}$ & $\begin{array}{l}8.75 \% * * * \\
(.5254)\end{array}$ & $(<.0001)$ & $\begin{array}{c}21.35 \% * * * \\
(.0022)\end{array}$ & $(.0008)$ \\
\hline \multirow{3}{*}{$\begin{array}{l}\text { No-crisis } \\
\text { sample: total }\end{array}$} & & & & & & & & & & & & \\
\hline & Negative & 1,369 & $40.21 \%$ & $39.54 \%$ & $39.16 \%$ & $37.78 \%$ & $38.12 \%$ & $38.37 \%$ & $-.71 \%$ & $(.3121)$ & $.85 \%$ & $(.1588)$ \\
\hline & Positive & 750 & $\begin{array}{r}40.23 \% \\
(.6189)\end{array}$ & $\begin{array}{r}40.92 \% \\
\quad(.3838)\end{array}$ & $\begin{array}{l}41.78 \% \\
(.1589)\end{array}$ & $\begin{array}{l}39.81 \% \\
(.0969)\end{array}$ & $\begin{array}{l}39.08 \% \\
\quad(.3200)\end{array}$ & $\begin{array}{l}41.30 \% \\
\quad(.1337)\end{array}$ & $\begin{array}{l}.62 \% * * \\
(.0307)\end{array}$ & $(.0288)$ & $\begin{array}{c}.60 \% \\
(.8016)\end{array}$ & $(.3514)$ \\
\hline \multirow{3}{*}{$\begin{array}{l}\text { Difference crisis- } \\
\text { no crisis } \\
(p \text { value })\end{array}$} & & & & & & & & & & & & \\
\hline & $\begin{array}{l}\text { Negative } \\
\text { Positive }\end{array}$ & & $(<.0001)$ & $(<.0001)$ & $(<.0001)$ & $(.0004)$ & $\begin{array}{l}(.5994) \\
(4419)\end{array}$ & $(.1028)$ & $(<.0001)$ & & $(.0021)$ & \\
\hline & Positive & & $(<.0001)$ & $(<.0001)$ & $(<.0001)$ & $(<.0001)$ & $(.4419)$ & $(.0001)$ & $(.3446)$ & & 1) & \\
\hline
\end{tabular}


Asian vs. Non-Asian Countries

\begin{tabular}{|c|c|c|c|c|c|c|c|c|c|c|c|c|}
\hline \multicolumn{13}{|l|}{ Asian countries: } \\
\hline \multirow[t]{2}{*}{ All } & Negative & 2,642 & $41.11 \%$ & $40.52 \%$ & $42.09 \%$ & $42.72 \%$ & $45.54 \%$ & $43.58 \%$ & $1.03 \% * * *$ & $(<.0001)$ & $1.37 \% * * *$ & $(<.0001)$ \\
\hline & Positive & 1,734 & $\begin{array}{l}36.83 \% \\
\quad(.0000)\end{array}$ & $\begin{array}{l}33.57 \% \\
(.0000)\end{array}$ & $\begin{array}{l}34.73 \% \\
\quad(.0000)\end{array}$ & $\begin{array}{l}35.64 \% \\
\quad(.0000)\end{array}$ & $\begin{array}{l}42.56 \% \\
\quad(.0036)\end{array}$ & $\begin{array}{l}44.09 \% \\
(.3124)\end{array}$ & $\begin{array}{r}-1.08 \% * \\
(.2897)\end{array}$ & $(.0662)$ & $\begin{array}{c}15.20 \% * * * \\
(.0011)\end{array}$ & $(<.0001)$ \\
\hline \multirow{3}{*}{$\begin{array}{l}\text { Non-Asian } \\
\text { countries: All }\end{array}$} & & & & & & & & & & & & \\
\hline & Negative & 1,701 & $25.26 \%$ & $28.75 \%$ & $29.48 \%$ & $29.13 \%$ & $29.33 \%$ & $27.95 \%$ & $14.03 \% * * *$ & $(<.0001)$ & $-2.87 \%$ & $(.9833)$ \\
\hline & Positive & 418 & $\begin{array}{l}20.77 \% \\
(.0356)\end{array}$ & $\begin{array}{l}20.03 \% \\
(.0000)\end{array}$ & $\begin{array}{l}22.41 \% \\
(.0000)\end{array}$ & $\begin{array}{l}22.98 \% \\
(.0023)\end{array}$ & $\begin{array}{l}26.71 \% \\
(.1337)\end{array}$ & $\begin{array}{l}25.58 \% \\
(.2304)\end{array}$ & $\begin{array}{l}.14 \% * * * \\
(.1386)\end{array}$ & $(.0070)$ & $\begin{array}{l}8.09 \% * * * \\
(.0000)\end{array}$ & $(.0002)$ \\
\hline \multicolumn{13}{|l|}{$\begin{array}{l}\text { Difference Asian- } \\
\text { Non-Asian }\end{array}$} \\
\hline ( $p$ value) & Negative & & $(<.0001)$ & $(<.0001)$ & $(<.0001)$ & $(<.0001)$ & $(<.0001)$ & $(<.0001)$ & $(<.0001)$ & & $(.0014)$ & \\
\hline & Positive & & $(<.0001)$ & $(<.0001)$ & $(<.0001)$ & $(<.0001)$ & $(<.0001)$ & $(<.0001)$ & $(.4953)$ & & $(.0570)$ & \\
\hline
\end{tabular}

Note.-Median Debt to Value Ratio by country and exchange rate beta. The debt-to-value ratio is calculated dividing total debt by the sum of total debt plus the book value of equity. Tests of significance are based on a Wilcoxon signed rank test. The third row in every panel is the p-value for a two-tailed test of equal medians in negative and positive exchange rate beta firms. We also report the p-value for a test of equality of medians crisis vs. no crisis sample, as well as Asian vs. non Asian countries.

$*, * *$ and $* * *$ indicate that the coefficient is significantly different from zero at the $0.1,0.05$ and 0.01 levels or better, respectively. 
their leverage while the positive-exchange-rate-beta firms decrease their leverage in Europe (median increase 13.66\%, significant at the $10 \%$ level, compared to a insignificant decrease of $1.86 \%$ ) and in Asia $(5.69 \%$ median increase versus a decrease of $3.92 \%$, significantly different at the 1\% level). In Latin America, both types of firms increase their leverage (13.46\% and $8.75 \%$ median increases). The results are reversed for the control sample, where negative-exchange-rate-beta firms decrease their leverage by an insignificant $0.71 \%$ and positiveexchange-rate-beta firms increase by $0.62 \%$ (significant at the $5 \%$ level). Hence, firms behave differently in the crisis sample and in the nocrisis sample depending on their exchange rate exposure. In general, in the crisis sample, the firms that have negative exposure increase their leverage more than positive-exposure firms. For the control sample, the opposite holds. Asia as whole (the crisis subsample from Asia plus Hong Kong and Japan) does not exhibit large increases in leverage.

In the 2 years that follow the currency depreciation, the patterns are reversed. In the crisis sample, positive-exchange-rate-beta firms increase their leverage significantly more than negative-exchange-ratebeta firms $(2.87 \%$ for negative-exposure firms and $14.97 \%$ for positive-exposure firms, significantly different at the $10 \%$ level). In the control sample, there is no change in leverage after the crisis.

On the regional level, we can observe clear differences. In Asia and Latin America, leverage increases for both types of firms after the crisis. In Asia, the positive-exposure firms increase their leverage by $25.00 \%$ (significant at the $1 \%$ level) and negative-exposure firms by $6.13 \%$ (also significant at the $1 \%$ level, and further, the difference is significant at the $1 \%$ level). Based on this evidence of increasing leverage, currency depreciations did not help alleviate financial distress problems, especially in Asia. The situation is markedly different in Europe for the 2 years after the crisis occurred. Negative-exposure firms show declining leverage in Europe in the 2 years following the crisis. The median decrease is $3.96 \%$ (significant at the $1 \%$ level). Moreover, debt-to-value ratios remain clearly on a higher level in Asia than in Europe or Latin America throughout the pre- and postcrisis periods. The Asian and non-Asian samples both exhibit big leverage increases for the positive ERB firms.

We also analyze the changes in short-term debt ratios to total debt, where short-term is defined as a maturity of less than 1 year. Results are in table 6. For the overall crisis sample and for Europe and Latin America, the median short-term debt to total debt ratio actually declines both in the 2 years before 2 and after a crisis. This holds for both negative- and positive-exchange-rate-beta firms. The Asian crisis subsample shows somewhat different results, since the negative-exposure firms show a significant increase in the 2 years preceding a crisis (an increase of $1.16 \%$, significant at the $1 \%$ level). Moreover, if we limit 
TABLE $6 \quad$ (Continued)

\begin{tabular}{|c|c|c|c|c|c|c|c|c|c|c|c|c|}
\hline \multirow[b]{2}{*}{ Region } & \multirow{2}{*}{$\begin{array}{l}\text { Exchange } \\
\text { Rate Beta }\end{array}$} & \multirow[b]{2}{*}{$N$} & \multirow[b]{2}{*}{$t=-3$} & \multirow[b]{2}{*}{$t=-2$} & \multirow[b]{2}{*}{$t=-1$} & \multirow[b]{2}{*}{$t=0$} & \multirow[b]{2}{*}{$t=+1$} & \multirow[b]{2}{*}{$t=+2$} & \multicolumn{2}{|c|}{$\begin{array}{c}\text { From }(t=-3) \text { to } \\
\quad(t=-1)\end{array}$} & \multicolumn{2}{|c|}{$\begin{array}{l}\text { From }(t=0) \text { to } \\
\quad(t=+2)\end{array}$} \\
\hline & & & & & & & & & Change & $p$ Value & Change & $p$ Value \\
\hline \multicolumn{13}{|c|}{ Asian vs. Non-Asian Countries } \\
\hline \multirow{3}{*}{$\begin{array}{l}\text { Asian countries: } \\
\text { all }\end{array}$} & & & & & & & & & & & & \\
\hline & Negative & 2,642 & $22.81 \%$ & $23.47 \%$ & $23.55 \%$ & $24.47 \%$ & $20.49 \%$ & $17.89 \%$ & $3.63 \% * * *$ & $(<.0001)$ & $-13.54 \% * * *$ & $(<.0001)$ \\
\hline & Positive & 1,734 & $\begin{array}{r}21.27 \% \\
(.8920)\end{array}$ & $\begin{array}{r}21.85 \% \\
(.3864)\end{array}$ & $\begin{array}{l}21.22 \% \\
\quad(.1437)\end{array}$ & $\begin{array}{r}22.78 \% \\
(.2050)\end{array}$ & $\begin{array}{r}20.47 \% \\
(.9595)\end{array}$ & $\begin{array}{c}17.86 \% \\
(.8141)\end{array}$ & $\begin{array}{l}1.11 \% * * * \\
(.1064)\end{array}$ & $\begin{array}{r}(.0000) \\
(<.0001)\end{array}$ & $\begin{array}{c}-8.98 \% * * * \\
(.7849)\end{array}$ & $(0.0023)$ \\
\hline \multirow[t]{2}{*}{$\begin{array}{l}\text { Non-Asian } \\
\quad \text { countries_-all }\end{array}$} & Negative & 1,701 & $12.27 \%$ & $11.03 \%$ & $9.58 \%$ & $9.34 \%$ & $8.43 \%$ & $8.01 \%$ & $-22.04 \% *$ & $(.0759)$ & $-11.75 \%$ & $(.3405)$ \\
\hline & Positive & 418 & $\begin{array}{r}12.25 \% \\
(.2302)\end{array}$ & $\begin{array}{r}12.94 \% \\
(.2649)\end{array}$ & $\begin{array}{r}12.18 \% \\
(.0338)\end{array}$ & $\begin{array}{r}10.79 \% \\
(.3530)\end{array}$ & $\begin{array}{l}9.14 \% \\
(.3852)\end{array}$ & $\begin{array}{l}8.68 \% \\
(.5103)\end{array}$ & $\begin{array}{l}-9.42 \% \\
(<.0001)\end{array}$ & $(.6133)$ & $\begin{array}{r}-13.13 \% \\
(.0516)\end{array}$ & $(.7905)$ \\
\hline $\begin{array}{l}\text { Difference Asian- } \\
\text { non-Asian } \\
\text { ( } p \text { value })\end{array}$ & $\begin{array}{l}\text { Negative } \\
\text { Positive }\end{array}$ & & $\begin{array}{l}(<.0001) \\
(<.0001)\end{array}$ & $\begin{array}{l}(<.0001) \\
(<.0001)\end{array}$ & $\begin{array}{l}(<.0001) \\
(<.0001)\end{array}$ & $\begin{array}{l}(<.0001) \\
(<.0001)\end{array}$ & $\begin{array}{l}(<.0001) \\
(<.0001)\end{array}$ & $\begin{array}{l}(<.0001) \\
(<.0001)\end{array}$ & $\begin{array}{l}(.1046) \\
(.3262)\end{array}$ & & $\begin{array}{r}(.6063) \\
(0321)\end{array}$ & \\
\hline
\end{tabular}

Note.-Median Short-Term Debt to Total Debt ratio. Short term debt refers to the portion of the debt repayable within one year. Tests of significance are based on a Wilcoxon signed rank test. The third row in every panel is the p-value for a two tailed test of equal medians in negative and positive exchange rate beta firms. We also report the p-value for a test of equality of medians crisis vs. no crisis sample, as well as Asian vs. non Asian countries.

$*, * *$ and $* * *$ indicate that the coefficient is significantly different from zero at the $0.1,0.05$ and 0.01 levels or better, respectively. 
attention to just the crisis year, Asian firms clearly resort to more shortterm financing. Interestingly, the no-crisis sample also exhibits increasing use of short-term debt prior to a crisis.

Our results concerning the increase in leverage are consistent with Pomerleano (1998) and Harvey and Roper (1999). These authors also document significant increases in short-term debt. Pomerleano (1998) documents the rapidly increasing debt ratios in Asia, specially shortterm, from 1992 to 1996. Harvey and Roper (1999) report that the median leverage ratio across the 261 firms in their sample was $68.6 \%$ in 1992 and $114 \%$ in 1996 . The leverage increase was mostly short-term again. We also document increases in short-term debt, especially for the negative-exposure firms, but the magnitude of increase in our sample is rather modest. However, during the crisis year, Asian firms clearly exhibit a jump in the amount of short-term borrowing.

In Claessens, Djankov, and Lang (1998), Asian firms also display increasing debt ratios, and their data suggest that the ratio of short-term debt to total debt in the Asian economies was significantly larger than in the United States or Germany (the median short-term debt share increased from $47.26 \%$ in 1988 to $60.43 \%$ in 1996 ; this ratio is $25.9 \%$ in 1996 in the United States, $45.3 \%$ in Germany). Our evidence is consistent with Claessens et al. (1998), since we also document that, in Asia, the percentage of short-term debt relative to total debt was clearly higher than in other regions.

In general, these results show that economies display increasing corporate leverage prior to a currency depreciation, particularly among companies that benefit from currency depreciations. The increase in leverage is not due to a relatively higher increase in short-term borrowing for European and Latin American companies. In addition, the no-crisis sample demonstrates no increases in overall leverage prior to the date of the currency attack, while there is an increase in the amount of short-term debt used. So, what differentiates crisis and no-crisis countries is not the changes in the amount of short-term debt but the changes in the overall level of leverage.

The increase in leverage for negative-exposure companies prior to a currency depreciation is consistent with Bris and Koskinen (2002), whereas the increase in leverage after a currency depreciation, especially among the positive-exposure firms, is consistent with Aghion et al. (2001). All in all, the results clearly show that firms in different sectors of the economy show distinct patterns before and after a crisis occurs. These patterns are consistent with Schneider and Tornell (2004), to the extent that our classification of firms based on their ERBs corresponds to the classification of traded and nontraded sectors used by Schneider and Tornell (2004).

In the next section, we analyze alternative measures of performance, profitability, and investment. 


\section{Other Variables}

\section{A. Profitability}

Harvey and Roper (1999), Claessens et al. (1998), and Pomerleano (1998) report a significant decline in profitability in Asian economies prior to the 1997 crisis (decreasing return on assets in Claessens et al. 1998; declining return on equity in Harvey and Roper 1999; and decreasing return on equity and return on capital employed in Pomerleano 1998). We want to examine whether this result extends to other regions and whether it is uniform across firms with different exposure to exchange rate movements.

We obtain data on two measures of profitability (earnings before interest and taxes over total revenues, or EBIT, and return on capital employed). The results are in tables 7 and 8 . We find significant declines in profitability under both measures and in the three regions under consideration for our crisis sample in the 2 years preceding the crisis. For the overall crisis sample, the EBIT to revenues ratio decreases for both negative- and positive-exposure companies the 2 years prior to a currency depreciation. The median decline is more severe for negative-exposure firms $(-30.05 \%$ for the negative-exposure firms compared to $-8.45 \%$ for the positive-exposure firms, significantly different at the $1 \%$ level). This result carries over to Europe and Asia, where the firms that have negative-exchange-rate betas have a bigger decrease in median profitability (the difference is significant, at least at the 5\% level). In the control sample and for the Latin American crisis sample, the positive-exposure firms show larger declines in EBIT to revenues ratio in the 2 years prior to a crisis.

After the currency depreciation, profitability decreases only for the positive-exposure firms in Europe and Latin America. Interestingly, this result does not hold for Asia, where EBIT to revenues ratio declines both for negative- and positive-exposure firms. The same results hold for our control sample. Based on changes in EBIT to revenues ratios, Asia is again different from other crisis regions: In Asia, all firms suffer declining profitability, whereas elsewhere only the positive-ERB firms show further decreases.

The other measure of profitability we use, the return on capital employed (ROCE), confirms that profitability decreases in the 2 years before a currency depreciation. In the overall crisis sample, both negative- and positive-exposure companies exhibit declining profitability, but again the negative-exposure firms suffer more (decreases of $3.26 \%$ and $2.64 \%$, respectively). Interestingly, now the control sample tells the opposite story: increase in ROCE for negative exposure firms and no decline in ROCE for positive exposure firms in the 2 years prior to a crisis. Asian firms, both in the crisis sample alone and grouped together with Hong Kong and Japan, clearly have lower 


\begin{tabular}{|c|c|c|c|c|c|c|c|c|c|c|c|c|}
\hline \multirow[b]{2}{*}{ Region } & \multirow{2}{*}{$\begin{array}{l}\text { Exchange } \\
\text { Rate Beta }\end{array}$} & \multirow[b]{2}{*}{$N$} & \multirow[b]{2}{*}{$t=-3$} & \multirow[b]{2}{*}{$t=-2$} & \multirow[b]{2}{*}{$t=-1$} & \multirow[b]{2}{*}{$t=0$} & \multirow[b]{2}{*}{$t=+1$} & \multirow[b]{2}{*}{$t=+2$} & \multicolumn{2}{|c|}{$\begin{array}{c}\text { From }(t=-3) \text { to } \\
\quad(t=-1)\end{array}$} & \multicolumn{2}{|c|}{$\begin{array}{l}\text { From }(t=0) \text { to } \\
\quad(t=+2)\end{array}$} \\
\hline & & & & & & & & & Change & $p$ Value & Change & $p$ Value \\
\hline \multicolumn{13}{|c|}{ Crisis vs. No-Crisis Countries } \\
\hline \multicolumn{13}{|l|}{ Crisis sample: } \\
\hline total & $\begin{array}{l}\text { Negative } \\
\text { Positive }\end{array}$ & $\begin{array}{r}2,114 \\
904\end{array}$ & $\begin{array}{c}9.51 \% \\
11.59 \% \\
(<.0001)\end{array}$ & $\begin{array}{c}7.42 \% \\
11.19 \% \\
(<.0001)\end{array}$ & $\begin{array}{c}6.72 \% \\
10.28 \% \\
(<.0001)\end{array}$ & $\begin{array}{c}5.74 \% \\
9.26 \% \\
(<.0001)\end{array}$ & $\begin{array}{c}5.87 \% \\
7.71 \% \\
(<.0001)\end{array}$ & $\begin{array}{c}6.43 \% \\
7.24 \% \\
(<.0001)\end{array}$ & $\begin{array}{c}-30.05 \% * * * \\
-8.45 \% * * * \\
(<.0001)\end{array}$ & $\begin{array}{l}(.0000) \\
(.0000)\end{array}$ & $\begin{array}{c}5.80 \% \\
-20.07 \% * * * \\
(.0000)\end{array}$ & $\begin{array}{l}(.2044) \\
(.0000)\end{array}$ \\
\hline \multicolumn{13}{|c|}{ ( } \\
\hline Europe & $\begin{array}{l}\text { Negative } \\
\text { Positive }\end{array}$ & $\begin{array}{r}1,066 \\
242\end{array}$ & $\begin{array}{c}10.23 \% \\
10.26 \% \\
(.8057)\end{array}$ & $\begin{array}{c}7.80 \% \\
10.24 \% \\
(<.0001)\end{array}$ & $\begin{array}{c}6.67 \% \\
9.24 \% \\
(<.0001)\end{array}$ & $\begin{array}{c}5.62 \% \\
8.12 \% \\
(<.0001)\end{array}$ & $\begin{array}{l}6.13 \% \\
7.53 \% \\
(.0036)\end{array}$ & $\begin{array}{l}6.71 \% \\
7.95 \% \\
(.0164)\end{array}$ & $\begin{array}{c}-35.26 \% * * * \\
-17.12 \% * * * \\
\quad(<.0001)\end{array}$ & $\begin{array}{r}(<.0001) \\
(.0001)\end{array}$ & $\begin{array}{c}8.03 \% \\
-13.52 \% * * * \\
(<.0001)\end{array}$ & $\begin{array}{r}(.3967) \\
(<.0001)\end{array}$ \\
\hline \multicolumn{13}{|l|}{ Crisis sample: } \\
\hline Asia & $\begin{array}{l}\text { Negative } \\
\text { Positive }\end{array}$ & $\begin{array}{l}967 \\
621\end{array}$ & $\begin{array}{c}8.66 \% \\
11.91 \% \\
(<.0001)\end{array}$ & $\begin{array}{c}6.79 \% \\
11.71 \% \\
(<.0001)\end{array}$ & $\begin{array}{c}6.71 \% \\
10.83 \% \\
(<.0001)\end{array}$ & $\begin{array}{c}5.86 \% \\
9.80 \% \\
(<.0001)\end{array}$ & $\begin{array}{c}5.69 \% \\
7.92 \% \\
(<.0001)\end{array}$ & $\begin{array}{l}5.83 \% \\
6.52 \% \\
(.0798)\end{array}$ & $\begin{array}{c}-25.39 \% * * * \\
-5.77 \% * * \\
(<.0001)\end{array}$ & $\begin{array}{r}(<.0001) \\
(.0374)\end{array}$ & $\begin{array}{c}-1.54 \% * * * \\
-30.08 \% * * * \\
(.0007)\end{array}$ & $\begin{array}{r}(.0056) \\
(<.0001)\end{array}$ \\
\hline \multicolumn{13}{|l|}{$\begin{array}{l}\text { Crisis sample: } \\
\text { Latin }\end{array}$} \\
\hline America & $\begin{array}{l}\text { Negative } \\
\text { Positive }\end{array}$ & $\begin{array}{l}81 \\
41\end{array}$ & $\begin{array}{c}10.03 \% \\
12.93 \% \\
(.2047)\end{array}$ & $\begin{array}{c}8.17 \% \\
11.36 \% \\
(.1057)\end{array}$ & $\begin{array}{c}8.73 \% \\
10.26 \% \\
(.3501)\end{array}$ & $\begin{array}{l}6.62 \% \\
9.55 \% \\
(.1003)\end{array}$ & $\begin{array}{l}6.02 \% \\
6.45 \% \\
(.8794)\end{array}$ & $\begin{array}{l}7.90 \% \\
9.95 \% \\
(.3935)\end{array}$ & $\begin{array}{c}-17.01 \% * * * \\
-31.25 \% * * * \\
(.3153)\end{array}$ & $\begin{array}{l}(.0002) \\
(.0091)\end{array}$ & $\begin{array}{r}10.20 \% \\
-7.66 \% \\
(.4752)\end{array}$ & $\begin{array}{l}(.2617) \\
(.9949)\end{array}$ \\
\hline \multicolumn{13}{|l|}{ No-crisis } \\
\hline sample: total & $\begin{array}{l}\text { Negative } \\
\text { Positive }\end{array}$ & $\begin{array}{l}856 \\
466\end{array}$ & $\begin{array}{l}3.23 \% \\
3.13 \% \\
(.3560)\end{array}$ & $\begin{array}{l}3.20 \% \\
3.45 \% \\
(.0705)\end{array}$ & $\begin{array}{l}3.38 \% \\
3.42 \% \\
(.7262)\end{array}$ & $\begin{array}{l}3.66 \% \\
3.25 \% \\
(.6976)\end{array}$ & $\begin{array}{l}2.98 \% \\
2.53 \% \\
(.1198)\end{array}$ & $\begin{array}{l}2.39 \% \\
1.78 \% \\
(.0633)\end{array}$ & $\begin{array}{c}-9.43 \% * * * \\
-18.37 \% * * * \\
(.0460)\end{array}$ & $\begin{array}{l}(<.0001) \\
(<.0001)\end{array}$ & $\begin{array}{c}-27.86 \% * * * \\
-36.22 \% * * * \\
(.1233)\end{array}$ & $\begin{array}{l}(<.0001) \\
(<.0001)\end{array}$ \\
\hline $\begin{array}{l}\text { Difference } \\
\text { crisis-no- } \\
\text { crisis } \\
\text { ( } p \text { value })\end{array}$ & $\begin{array}{l}\text { Negative } \\
\text { Positive }\end{array}$ & & $\begin{array}{l}(<.0001) \\
(<.0001)\end{array}$ & $\begin{array}{l}(<.0001) \\
(<.0001)\end{array}$ & $\begin{array}{l}(<.0001) \\
(<.0001)\end{array}$ & $\begin{array}{r}(.0004) \\
(<.0001)\end{array}$ & $\begin{array}{l}(.5994) \\
(.4419)\end{array}$ & $\begin{array}{l}(.1028) \\
(.0001)\end{array}$ & $\begin{array}{r}(<.0001) \\
(.0130)\end{array}$ & & $\begin{array}{r}(<.0001) \\
(.0105)\end{array}$ & \\
\hline
\end{tabular}


TABLE 7 (Continued)

\begin{tabular}{|c|c|c|c|c|c|c|c|c|c|c|c|c|}
\hline \multirow[b]{2}{*}{ Region } & \multirow{2}{*}{$\begin{array}{l}\text { Exchange } \\
\text { Rate Beta }\end{array}$} & \multirow[b]{2}{*}{$N$} & \multirow[b]{2}{*}{$t=-3$} & \multirow[b]{2}{*}{$t=-2$} & \multirow[b]{2}{*}{$t=-1$} & \multirow[b]{2}{*}{$t=0$} & \multirow[b]{2}{*}{$t=+1$} & \multirow[b]{2}{*}{$t=+2$} & \multicolumn{2}{|c|}{$\begin{array}{c}\text { From }(t=-3) \text { to } \\
\quad(t=-1)\end{array}$} & \multicolumn{2}{|c|}{$\begin{array}{l}\text { From }(t=0) \text { to } \\
\quad(t=+2)\end{array}$} \\
\hline & & & & & & & & & Change & $p$ Value & Change & $p$ Value \\
\hline \multicolumn{13}{|c|}{ Asian vs. Non-Asian Countries } \\
\hline $\begin{array}{l}\text { Asian countries: } \\
\text { all }\end{array}$ & $\begin{array}{l}\text { Negative } \\
\text { Positive }\end{array}$ & $\begin{array}{l}1,846 \\
1,103\end{array}$ & $\begin{array}{c}11.39 \% \\
6.83 \% \\
(<.0001)\end{array}$ & $\begin{array}{c}10.45 \% \\
7.56 \% \\
(<.0001)\end{array}$ & $\begin{array}{l}9.33 \% \\
7.46 \% \\
(.0012)\end{array}$ & $\begin{array}{l}8.18 \% \\
6.50 \% \\
(.0475)\end{array}$ & $\begin{array}{l}7.52 \% \\
4.83 \% \\
(.0002)\end{array}$ & $\begin{array}{c}8.44 \% \\
3.10 \% \\
(<.0001)\end{array}$ & $\begin{array}{c}-18.85 \% * * * \\
-10.05 \% * * * \\
(.3361)\end{array}$ & $\begin{array}{l}(<.0001) \\
(<.0001)\end{array}$ & $\begin{array}{c}-18.74 \% * * * \\
33.36 \% * * * \\
(.0005)\end{array}$ & $\begin{array}{l}(<.0001) \\
(<.0001)\end{array}$ \\
\hline $\begin{array}{l}\text { Non Asian } \\
\text { countries: all }\end{array}$ & $\begin{array}{l}\text { Negative } \\
\text { Positive }\end{array}$ & $\begin{array}{r}1,167 \\
297\end{array}$ & $\begin{array}{c}10.23 \% \\
5.53 \% \\
(<.0001)\end{array}$ & $\begin{array}{l}7.84 \% \\
5.02 \% \\
(<.0001)\end{array}$ & $\begin{array}{l}6.73 \% \\
5.03 \% \\
(<.0001)\end{array}$ & $\begin{array}{l}5.64 \% \\
4.72 \% \\
(.0112)\end{array}$ & $\begin{array}{c}6.16 \% \\
3.87 \% \\
(<.0001)\end{array}$ & $\begin{array}{c}6.89 \% \\
3.27 \% \\
(<.0001)\end{array}$ & $\begin{array}{c}-33.72 \% * * * \\
-17.82 \% * * * \\
(<.0001)\end{array}$ & $\begin{array}{l}(<.0001) \\
(<.0001)\end{array}$ & $\begin{array}{c}8.56 \% \\
-11.63 \% * * * \\
(.0000)\end{array}$ & $\begin{array}{r}(.2478) \\
(<.0001)\end{array}$ \\
\hline $\begin{array}{l}\text { Difference Asian } \\
\text { non-Asian } \\
\text { ( } p \text { value })\end{array}$ & $\begin{array}{l}\text { Negative } \\
\text { Positive }\end{array}$ & & $\begin{array}{l}(.3191) \\
(.0016)\end{array}$ & $\begin{array}{l}(<.0001) \\
(<.0001)\end{array}$ & $\begin{array}{l}(<.0001) \\
(<.0001)\end{array}$ & $\begin{array}{l}(<.0001) \\
(<.0001)\end{array}$ & $\begin{array}{l}(<.0001) \\
(<.0001)\end{array}$ & $\begin{array}{l}(.0061) \\
(.5981)\end{array}$ & $\begin{array}{r}(<.0001) \\
(.0205)\end{array}$ & & $\begin{array}{r}(<.0001) \\
(.0009)\end{array}$ & \\
\hline
\end{tabular}

NotE.- Median EBIT to Revenues Ratio Tests significance are based on a Wilcoxon signed rank test. The third row in every panel is the p-value for a two tailed test of equal medians in negative and positive exchange rate beta firms. We also report the p-value for a test of equality of medians crisis vs. no crisis sample, as well as Asian vs. non Asian countries.

$*, * *$ and $* * *$ indicate that the coefficient is significantly different from zero at the $0.1,0.05$ and 0.01 levels or better, respectively. 


\begin{tabular}{|c|c|c|c|c|c|c|c|c|c|c|c|c|}
\hline \multirow[b]{2}{*}{ Region } & \multirow{2}{*}{$\begin{array}{l}\text { Exchange } \\
\text { Rate Beta }\end{array}$} & \multirow[b]{2}{*}{$N$} & \multirow[b]{2}{*}{$t=-3$} & \multirow[b]{2}{*}{$t=-2$} & \multirow[b]{2}{*}{$t=-1$} & \multirow[b]{2}{*}{$t=0$} & \multirow[b]{2}{*}{$t=+1$} & \multirow[b]{2}{*}{$t=+2$} & \multicolumn{2}{|c|}{$\begin{array}{l}\text { From }(t=-3) \text { to } \\
\qquad(t=-1)\end{array}$} & \multicolumn{2}{|c|}{$\begin{array}{l}\text { From }(t=0) \text { to } \\
\quad(t=+2)\end{array}$} \\
\hline & & & & & & & & & Change & $p$ Value & Change & $p$ Value \\
\hline \multicolumn{13}{|c|}{ Crisis vs. No-Crisis Countries } \\
\hline \multicolumn{13}{|l|}{ Crisis sample: } \\
\hline total & Negative & 2,058 & $13.37 \%$ & $11.86 \%$ & $10.23 \%$ & $8.59 \%$ & $7.57 \%$ & $8.50 \%$ & $-3.26 \% * * *$ & $(<.0001)$ & $-.76 \% * * *$ & $(<.0001)$ \\
\hline & Positive & 857 & $\begin{array}{r}11.76 \% \\
(.0361)\end{array}$ & $\begin{array}{c}10.49 \% \\
(.0390)\end{array}$ & $\begin{array}{c}10.12 \% \\
(.9594)\end{array}$ & $\begin{array}{l}8.27 \% \\
(.3724)\end{array}$ & $\begin{array}{l}6.90 \% \\
(.3866)\end{array}$ & $\begin{array}{r}6.54 \% \\
(.0004)\end{array}$ & $\begin{array}{c}-2.64 \% * * * \\
(.0447)\end{array}$ & $(<.0001)$ & $\begin{array}{c}-1.91 \% * * * \\
(.0042)\end{array}$ & $(<.0001)$ \\
\hline \multicolumn{13}{|l|}{ Crisis sample: } \\
\hline Europe & Negative & 1,131 & $19.89 \%$ & $17.77 \%$ & $14.51 \%$ & $12.00 \%$ & $11.25 \%$ & $11.91 \%$ & $-5.71 \% * * *$ & $(<.0001)$ & $-.14 \%$ & $(.8103)$ \\
\hline & Positive & 262 & $\begin{array}{l}18.04 \% \\
(.7453)\end{array}$ & $\begin{array}{l}16.64 \% \\
(.7472)\end{array}$ & $\begin{array}{l}13.92 \% \\
(.3705)\end{array}$ & $\begin{array}{l}12.16 \% \\
(.6772)\end{array}$ & $\begin{array}{l}11.91 \% \\
(.1228)\end{array}$ & $\begin{array}{l}11.63 \% \\
(.7358)\end{array}$ & $\begin{array}{c}-4.61 \% * * * \\
(.2463)\end{array}$ & $(<.0001)$ & $\begin{array}{r}-.46 \% \\
(.6840)\end{array}$ & $(.6075)$ \\
\hline \multicolumn{13}{|l|}{ Crisis sample: } \\
\hline Asia & Negative & 869 & $7.57 \%$ & $7.97 \%$ & $7.73 \%$ & $6.41 \%$ & $4.62 \%$ & $4.24 \%$ & $-1.43 \% * * *$ & $(<.0001)$ & $-2.33 \% * * *$ & $(<.0001)$ \\
\hline & Positive & 567 & $\begin{array}{c}9.66 \% \\
(<.0001)\end{array}$ & $\begin{array}{l}9.06 \% \\
(.0001)\end{array}$ & $\begin{array}{c}8.63 \% \\
(<.0001)\end{array}$ & $\begin{array}{l}7.29 \% \\
(.0001)\end{array}$ & $\begin{array}{l}5.47 \% \\
(.0001)\end{array}$ & $\begin{array}{l}4.14 \% \\
(.3237)\end{array}$ & $\begin{array}{c}-1.99 \% * * * \\
(.1249)\end{array}$ & $(<.0001)$ & $\begin{array}{c}-3.50 \% * * * \\
(.3726)\end{array}$ & $(<.0001)$ \\
\hline \multicolumn{13}{|l|}{$\begin{array}{l}\text { Crisis sample: } \\
\text { Latin }\end{array}$} \\
\hline America & Negative & 58 & $17.32 \%$ & $15.07 \%$ & $12.24 \%$ & $10.85 \%$ & $7.59 \%$ & $11.08 \%$ & $-5.29 \% * * *$ & $(.0001)$ & $-.44 \%$ & $(.6695)$ \\
\hline & Positive & 28 & $\begin{array}{l}17.24 \% \\
(.7898)\end{array}$ & $\begin{array}{c}19.33 \% \\
(.6064)\end{array}$ & $\begin{array}{c}17.44 \% \\
(.0488)\end{array}$ & $\begin{array}{l}9.72 \% \\
(.9118)\end{array}$ & $\begin{array}{l}4.12 \% \\
(.8443)\end{array}$ & $\begin{array}{c}10.61 \% \\
(.7575)\end{array}$ & $\begin{array}{r}-1.42 \% \\
\quad(.3370)\end{array}$ & $(.7969)$ & $\begin{array}{l}2.18 \% \\
(.2902)\end{array}$ & $(.4964)$ \\
\hline \multicolumn{13}{|c|}{ 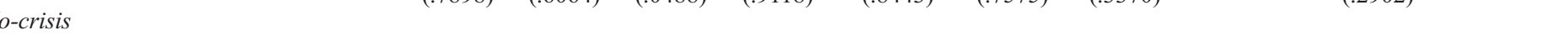 } \\
\hline sample: total & Negative & 717 & $4.47 \%$ & $4.60 \%$ & $4.72 \%$ & $5.21 \%$ & $4.63 \%$ & $3.68 \%$ & $.59 \% * *$ & $(.0145)$ & $-1.68 \% * * *$ & $(<.0001)$ \\
\hline & Positive & 397 & $\begin{array}{l}5.05 \% \\
(.1391)\end{array}$ & $\begin{array}{l}5.23 \% \\
(.2147)\end{array}$ & $\begin{array}{l}4.56 \% \\
(.8538)\end{array}$ & $\begin{array}{l}4.88 \% \\
(.3576)\end{array}$ & $\begin{array}{l}3.95 \% \\
(.0149)\end{array}$ & $\begin{array}{l}2.84 \% \\
(.0002)\end{array}$ & $\begin{array}{l}.01 \% \\
(.0517)\end{array}$ & .4023 & $\begin{array}{l}-2.82 \% * * * \\
(<.0001)\end{array}$ & $(<.0001)$ \\
\hline $\begin{array}{l}\text { Difference } \\
\text { crisis-No- } \\
\text { crisis ( } p \text { value) }\end{array}$ & $\begin{array}{l}\text { Negative } \\
\text { Positive }\end{array}$ & & $\begin{array}{l}(<.0001) \\
(<.0001)\end{array}$ & $\begin{array}{l}(<.0001) \\
(<.0001)\end{array}$ & $\begin{array}{l}(<.0001) \\
(<.0001)\end{array}$ & $\begin{array}{l}(<.0001) \\
(<.0001)\end{array}$ & $\begin{array}{l}(<.0001) \\
(<.0001)\end{array}$ & $\begin{array}{l}(<.0001) \\
(<.0001)\end{array}$ & $\begin{array}{l}(<.0001) \\
(<.0001)\end{array}$ & & $\begin{array}{l}(<.0001) \\
(<.0001)\end{array}$ & \\
\hline
\end{tabular}


TABLE 8 (Continued)

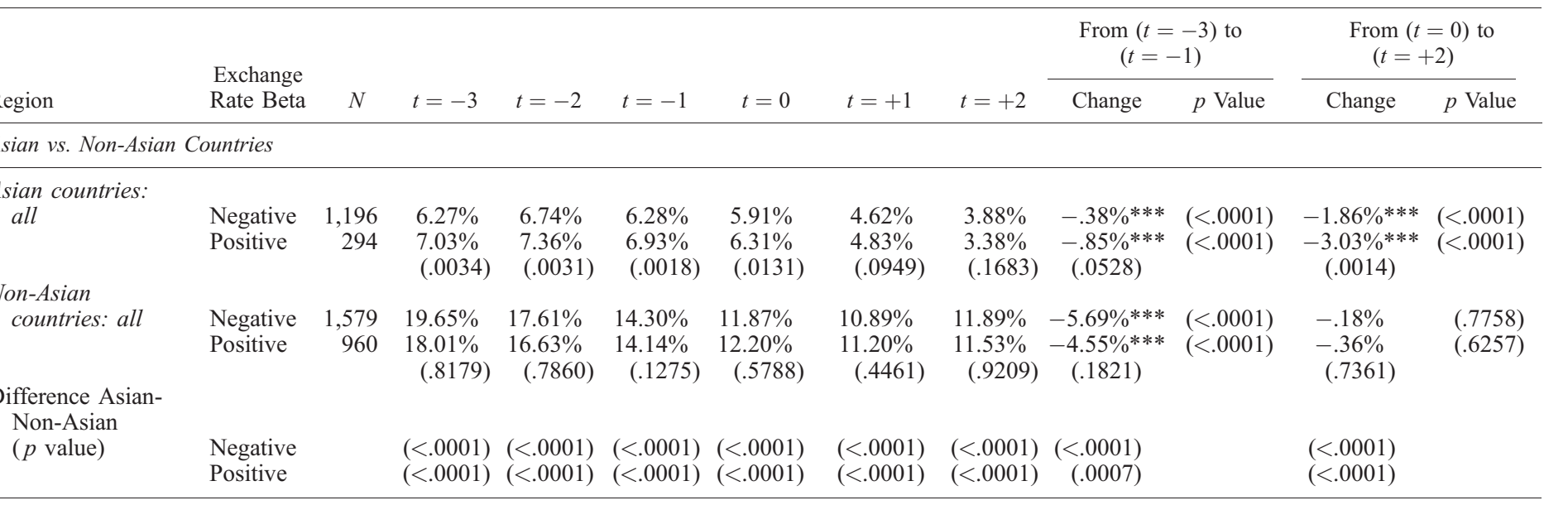

NotE.- Median Return on Capital Emplyed (ROCE). Tests of significance are based on a Wilcoxon signed rank test. The third row in every panel is the p-value for a two tailed test of equal medians in negative and positive exchange rate beta firms. We also report the p-value for a test of equality of medians crisis vs. no crisis sample, as well as Asian vs. non Asian countries.

$*, * *$ and $* *$ indicate that the coefficient is significantly different from zero at the $0.1,0.05$ and 0.01 levels or better, respectively. 
profitability than European and Latin American firms both before and after the crises.

After currency depreciation, we observe no improvement in ROCE for the overall crisis sample. This result is, however, due to adverse development in Asia after the crisis, consistent with the previous result using EBIT to revenues ratio as a measure of profitability. After a currency depreciation, the profitability of all firms in Asia declines no matter what the measure. The same is true for the control sample. In Europe and Latin America, there is no significant change in ROCE after the currency depreciations. These results confirm that the Asian crisis is different from the European and Latin American ones. Further declines in Asia for all firms, but in Europe and Latin America, only the positive-ERB firms have declining profitability if EBIT to revenues is used as the measure. If ROCE is used as a measure of profitability, then neither negative- nor positive-exposure firms in Europe and Latin America show further decreases in profitability.

\section{B. Financial Fragility}

Radelet and Sachs (1998) blame financial panic as a cause of the East Asia crises of 1997. They identify the ratio of short-term debt to foreign exchange reserves as an indicator of a country's risk. Radelet and Sachs (1998) report that this ratio was above 1 for Indonesia, Thailand, and South Korea prior to 1997. However, it was also below 1 for some other countries affected by the crises, such as Taiwan and the Philippines.

We study financial fragility in a similar fashion to Radelet and Sachs (1998), except that we use firm-level data. In our analysis, the current ratio measures the ability of a creditor to pay off its short-term debts. The current ratio is calculated as current assets to current liabilities, and it reflects the current liquidity of the firm. Pomerleano (1998) argues that this would be a good measure of a firm's financial fragility, although the ratio is not reported in his study.

We report in table 9 the current ratio for 2994 firms in our crisis sample and 1304 firms in our control sample. The evolution of the current ratio differs across firms, depending on their currency exposure. While negative-exposure firms decrease their current ratio by $5.00 \%$ (significant at the 1\% level), the change for positive exposure is insignificant for the overall crisis sample. The evidence differs somewhat, depending on the crisis region: For all the regions, negative-exposure companies have a significant decline in current ratio, but for positiveexposure firms, the evidence is divergent. In Europe, the positive-ERB firms exhibit even greater decline in current ratio than the negative ones, whereas in Latin America the positive-exposure firms become less fragile. For the control sample, the decline in the current ratio is about the same for all firms. It is interesting to note that- for the United States, 


\begin{tabular}{|c|c|c|c|c|c|c|c|c|c|c|c|c|}
\hline \multirow[b]{2}{*}{ Region } & \multirow{2}{*}{$\begin{array}{l}\text { Exchange } \\
\text { Rate Beta }\end{array}$} & \multirow[b]{2}{*}{$N$} & \multirow[b]{2}{*}{$t=-3$} & \multirow[b]{2}{*}{$t=-2$} & \multirow[b]{2}{*}{$t=-1$} & \multirow[b]{2}{*}{$t=0$} & \multirow[b]{2}{*}{$t=+1$} & \multirow[b]{2}{*}{$t=+2$} & \multicolumn{2}{|c|}{$\begin{array}{c}\text { From } \begin{aligned}(t & =-3) \text { to } \\
(t & =-1)\end{aligned}\end{array}$} & \multicolumn{2}{|c|}{$\begin{array}{c}\text { From }(t=0) \text { to } \\
\quad(t=+2)\end{array}$} \\
\hline & & & & & & & & & Change & $p$ Value & Change & $p$ Value \\
\hline \multicolumn{13}{|c|}{ Crisis vs. no-crisis countries } \\
\hline Crisis sample: & & & & & & & & & & & & \\
\hline total & $\begin{array}{l}\text { Negative } \\
\text { Positive }\end{array}$ & $\begin{array}{r}2,049 \\
945\end{array}$ & $\begin{array}{l}1.40 \\
1.34 \\
(.0794)\end{array}$ & $\begin{array}{l}1.39 \\
1.38 \\
(.4834)\end{array}$ & $\begin{array}{l}1.33 \\
1.40 \\
(.0325)\end{array}$ & $\begin{array}{l}1.32 \\
1.38 \\
(.0181)\end{array}$ & $\begin{array}{l}1.25 \\
1.22 \\
(.9307)\end{array}$ & $\begin{array}{l}1.27 \\
1.21 \\
(.0564)\end{array}$ & $\begin{array}{l}-5.00 \% * * * \\
-2.00 \% \\
(.2261)\end{array}$ & $\begin{array}{r}(<.0001) \\
(.1718)\end{array}$ & $\begin{array}{r}-3.00 \% \\
-11.00 \% \\
(.0005)\end{array}$ & $\begin{array}{l}(<.0001) \\
(<.0001)\end{array}$ \\
\hline Crisis sample: & & & & & & & & & & & & \\
\hline Europe & $\begin{array}{l}\text { Negative } \\
\text { Positive }\end{array}$ & $\begin{array}{r}1,019 \\
235\end{array}$ & $\begin{array}{l}1.39 \\
1.43 \\
(.6215)\end{array}$ & $\begin{array}{l}1.34 \\
1.36 \\
(.7654)\end{array}$ & $\begin{array}{l}1.32 \\
1.33 \\
(.7256)\end{array}$ & $\begin{array}{l}1.34 \\
1.29 \\
(.2417)\end{array}$ & $\begin{array}{l}1.35 \\
1.32 \\
(.5769)\end{array}$ & $\begin{array}{l}1.37 \\
1.41 \\
(.5310)\end{array}$ & $\begin{array}{c}-4.00 \% * * * \\
-8.00 \% * * * \\
(.0684)\end{array}$ & $\begin{array}{l}(.0009) \\
(.0011)\end{array}$ & $\begin{array}{l}1.00 \% \\
6.00 \% \\
(.0810)\end{array}$ & $\begin{array}{l}(.2991) \\
(.0226)\end{array}$ \\
\hline Crisis sample: & & & & & & & & & & & & \\
\hline Asia & $\begin{array}{l}\text { Negative } \\
\text { Positive }\end{array}$ & $\begin{array}{l}952 \\
673\end{array}$ & $\begin{array}{l}1.38 \\
1.32 \\
(.1232)\end{array}$ & $\begin{array}{l}1.43 \\
1.38 \\
(.9284)\end{array}$ & $\begin{array}{l}1.36 \\
1.41 \\
(.0843)\end{array}$ & $\begin{array}{l}1.29 \\
1.44 \\
(.0011)\end{array}$ & $\begin{array}{l}1.13 \\
1.17 \\
(.0662)\end{array}$ & $\begin{array}{l}1.12 \\
1.07 \\
(.5809)\end{array}$ & $\begin{array}{c}-6.00 \% * * * \\
-1.00 \% \\
(.0551)\end{array}$ & $\begin{array}{l}(.0002) \\
(.8083)\end{array}$ & $\begin{array}{r}-12.00 \% \\
-23.00 \% \\
(.0021)\end{array}$ & $\begin{array}{l}(<.0001) \\
(<.0001)\end{array}$ \\
\hline $\begin{array}{l}\text { Crisis sample: } \\
\text { Latin }\end{array}$ & & & & & & & & & & & & \\
\hline America & $\begin{array}{l}\text { Negative } \\
\text { Positive }\end{array}$ & $\begin{array}{l}78 \\
37\end{array}$ & $\begin{array}{l}1.66 \\
1.36 \\
(.0567)\end{array}$ & $\begin{array}{l}1.65 \\
1.61 \\
(.9314)\end{array}$ & $\begin{array}{l}1.49 \\
1.72 \\
(.0688)\end{array}$ & $\begin{array}{l}1.56 \\
1.49 \\
(.4607)\end{array}$ & $\begin{array}{l}1.35 \\
1.43 \\
(.1031)\end{array}$ & $\begin{array}{l}1.44 \\
1.69 \\
(.0966)\end{array}$ & $\begin{array}{c}-18.000 \% * * * \\
28.00 \% * * \\
(.0006)\end{array}$ & $\begin{array}{l}(.0013) \\
(.0362)\end{array}$ & $\begin{array}{r}-10.00 \% \\
8.00 \% \\
(.1393)\end{array}$ & $\begin{array}{l}(.0078) \\
(.8344)\end{array}$ \\
\hline $\begin{array}{l}\text { No-crisis } \\
\quad \text { sample: total }\end{array}$ & $\begin{array}{l}\text { Negative } \\
\text { Positive }\end{array}$ & $\begin{array}{l}825 \\
479\end{array}$ & $\begin{array}{l}1.39 \\
1.30 \\
(.0053)\end{array}$ & $\begin{array}{l}1.36 \\
1.28 \\
(.0227)\end{array}$ & $\begin{array}{l}1.33 \\
1.26 \\
(.0154)\end{array}$ & $\begin{array}{l}1.31 \\
1.24 \\
(.0616)\end{array}$ & $\begin{array}{l}1.28 \\
1.22 \\
(.0242)\end{array}$ & $\begin{array}{l}1.33 \\
1.25 \\
(.0052)\end{array}$ & $\begin{array}{c}-5.00 \% * * * \\
-4.00 \% * * * \\
(.8064)\end{array}$ & $\begin{array}{l}(<.0001) \\
(<.0001)\end{array}$ & $\begin{array}{l}3.00 \% \\
.00 \% \\
(.0050)\end{array}$ & $\begin{array}{r}(<.0001) \\
(.8523)\end{array}$ \\
\hline $\begin{array}{l}\text { Difference } \\
\text { crisis-no } \\
\text { crisis } \\
\text { ( } p \text { value })\end{array}$ & $\begin{array}{l}\text { Negative } \\
\text { Positive }\end{array}$ & & $\begin{array}{l}(.1008) \\
(.9810)\end{array}$ & $\begin{array}{l}(.5709) \\
(.0352)\end{array}$ & $\begin{array}{l}(.9428) \\
(.0002)\end{array}$ & $\begin{array}{l}(.6657) \\
(.0034)\end{array}$ & $\begin{array}{l}(.0004) \\
(.5688)\end{array}$ & $\begin{array}{r}(<.0001) \\
(.0707)\end{array}$ & $\begin{array}{l}(.2128) \\
(.0419)\end{array}$ & & $\begin{array}{l}(<.0001) \\
(<.0001)\end{array}$ & \\
\hline
\end{tabular}




\begin{tabular}{|c|c|c|c|c|c|c|c|c|c|c|c|c|}
\hline \multicolumn{13}{|c|}{ Asian vs. Non-Asian Countries } \\
\hline \multicolumn{13}{|l|}{ Asian countries: } \\
\hline \multirow[t]{3}{*}{ all } & Negative & 1,768 & 1.41 & 1.36 & 1.32 & 1.36 & 1.35 & 1.37 & $-5.00 \% * * *$ & $(<.0001)$ & $-2.00 \%$ & $(0.0388)$ \\
\hline & Positive & 1,148 & 1.42 & 1.40 & 1.39 & 1.33 & 1.33 & 1.45 & $-3.00 \% * * *$ & $(.0006)$ & $-7.00 \%$ & $(<.0001)$ \\
\hline & & 1,106 & $(.1106)$ & $(.4970)$ & $(.8530)$ & $(.5620)$ & $(.0124)$ & $(<.0001)$ & $(.1742)$ & & $(<.0001)$ & \\
\hline \multicolumn{13}{|l|}{ Non-Asian } \\
\hline \multirow[t]{3}{*}{ countries: all } & Negative & 276 & 1.38 & 1.39 & 1.34 & 1.30 & 1.20 & 1.24 & $-5.00 \% * * *$ & $(.0001)$ & $.00 \% *$ & $(.8360)$ \\
\hline & Positive & & 1.31 & 1.33 & 1.35 & 1.34 & 1.20 & 1.16 & $-6.00 \% * *$ & $(.0318)$ & $6.00 \%$ & $(.0503)$ \\
\hline & & & $(.9084)$ & $(.0436)$ & $(.5296)$ & $(.1276)$ & $(<.0001)$ & $(<.0001)$ & $(.5516)$ & & $(.0670)$ & \\
\hline \multicolumn{13}{|l|}{$\begin{array}{l}\text { Difference Asian- } \\
\text { Non-Asian }\end{array}$} \\
\hline \multirow[t]{2}{*}{ ( $p$ value $)$} & Negative & & $(.7573)$ & $(.3505)$ & $(.4908)$ & $(.5925)$ & $(.8872)$ & $(.2150)$ & $(.0820)$ & & $(.1177)$ & \\
\hline & Positive & & $(.0024)$ & $(.1045)$ & $(.9580)$ & $(.1376)$ & $(.7703)$ & $(.0141)$ & $(.6095)$ & & $(<.0001)$ & \\
\hline
\end{tabular}

Note.-Median Current Assets to Current Liabilities Ratio. Tests of significance are based on a Wilcoxon signed rank test. The third row in every panel is the p-value for a two tailed test of equal medians in negative and positive exchange rate beta firms. We also report the p-value for a test of equality of medians crisis vs. no crisis sample, as well as Asian vs. non Asian countries.

$*, * *$ and $* * *$ indicate that the coefficient is significantly different from zero at the $0.1,0.05$ and 0.01 levels or better, respectively. 
the current ratio for the total sample of Compustat firms (5108 firms with data available) in the years $1995-1998$ is respectively $3.29,3.70$, 4.04 , and 3.34, considerably higher than either in our crisis or control samples.

Interestingly, for 2 years after the crisis, the current ratio still declined for Asian firms (a decline of $12.00 \%$ for the negative-exposure firms and $23.00 \%$ for the positive-exposure firms, both significant at the $1 \%$ level), whereas in Europe the positive-ERB firms show increasing current ratio and in Latin America only the negative-exposure firms decreased their current ratios. This is further evidence that the Asian firms have been slower in their recovery than European and Latin American firms.

Table 10 complements the previous result. We display the interest coverage ratios for the firms in the sample and find a clear deterioration in solvency for both negative- and positive-exposure firms prior to the onset of the corresponding crisis. The interest coverage ratio is calculated as EBITDA divided by interest expense, where EBITDA are the company's earnings before total interest expense, depreciation, amortization, and provisions. For the overall crisis sample, negative-exchange-rate-beta firms experienced a decrease of $40.25 \%$ in their interest coverage ratio, while firms with a positive-exchange-rate betas decreased their interest coverage ratio by $30.79 \%$, both coefficients significantly different from zero at $1 \%$ level. For European firms, the change in interest coverage ratio declined for both types of firms $(-50.47 \%$ change for negativeexposure firms and $-44.42 \%$ change for the positive-exposure firms, both significant at the $1 \%$ level). For Asian firms, the negative-exposure firms show a significant decline in interest coverage (a decrease of $7.09 \%$, significant at the $1 \%$ level). It is especially interesting to observe that the level of interest coverage was very low for Asian firms already several years before the onset of the crisis, especially for the negativeERB firms. Also noteworthy is the observation that, in our control sample, positive-exposure firms significantly increased their interest coverage ratios prior to the attacks (an increase of $11.18 \%$ for positive exposure firms, significant at the $1 \%$ level).

For European firms, the interest coverage ratio increased significantly (an increase of $8.56 \%$ for the negative-ERB firms) during the 2 years following the currency crisis, while for the Asian firms, the interest coverage ratio declined even further (a decline of $35.80 \%$ for negative-exposure firms and $45.07 \%$ for the positive-exposure firms, both significant at the $1 \%$ level). Analysis of the interest coverage ratio further confirms the special characteristics of the Asian crisis with respect to the turbulences in Europe and Latin America. Moreover, interest coverage is markedly lower in Asia during the 6 years that we study compared to Europe and Latin America. After 2 years following the onset of the crisis, interest coverage was below 1 for negative-ERB 


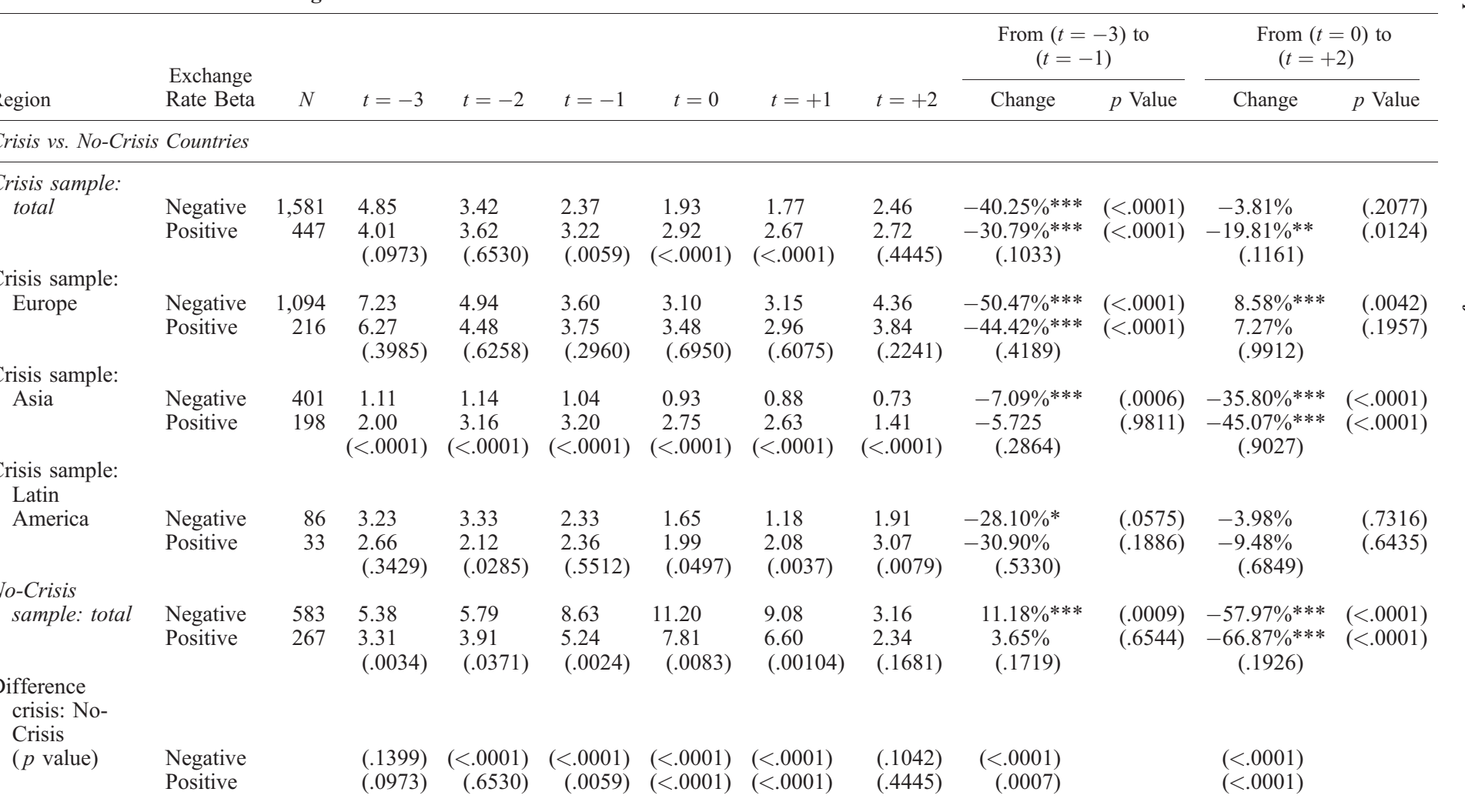




\section{TABLE $10 \quad$ (Continued)}

\begin{tabular}{|c|c|c|c|c|c|c|c|c|c|c|c|c|}
\hline \multirow[b]{2}{*}{ Region } & \multirow{2}{*}{$\begin{array}{l}\text { Exchange } \\
\text { Rate Beta }\end{array}$} & \multirow[b]{2}{*}{$N$} & \multirow[b]{2}{*}{$t=-3$} & \multirow[b]{2}{*}{$t=-2$} & \multirow[b]{2}{*}{$t=-1$} & \multirow[b]{2}{*}{$t=0$} & \multirow[b]{2}{*}{$t=+1$} & \multirow[b]{2}{*}{$t=+2$} & \multicolumn{2}{|c|}{$\begin{array}{c}\text { From }(t=-3) \text { to } \\
t=-1\end{array}$} & \multicolumn{2}{|c|}{$\begin{array}{c}\text { From }(t=0) \text { to } \\
\quad t=+2\end{array}$} \\
\hline & & & & & & & & & Change & $p$ Value & Change & $p$ Value \\
\hline \multicolumn{13}{|c|}{ Asian vs. Non-Asian Countries } \\
\hline Asian countries: & & & & & & & & & & & & \\
\hline all & $\begin{array}{l}\text { Negative } \\
\text { Positive }\end{array}$ & $\begin{array}{l}976 \\
460\end{array}$ & $\begin{array}{l}1.84 \\
2.68 \\
(<.0001)\end{array}$ & $\begin{array}{l}1.89 \\
3.58 \\
(0.2622)\end{array}$ & $\begin{array}{l}1.90 \\
4.05 \\
(.8103)\end{array}$ & $\begin{array}{l}2.28 \\
4.06 \\
(.0147)\end{array}$ & $\begin{array}{l}1.68 \\
3.52 \\
(.0071)\end{array}$ & $\begin{array}{l}1.19 \\
1.80 \\
(<.0001)\end{array}$ & $\begin{array}{l}-.06 \% \\
-.02 \% \\
(<.0001)\end{array}$ & $\begin{array}{l}(.5006) \\
(.8293)\end{array}$ & $\begin{array}{l}-49.58 \% * * * \\
-55.03 \% * * * \\
(<.0001)\end{array}$ & $\begin{array}{l}(<.0001) \\
(<.0001)\end{array}$ \\
\hline $\begin{array}{l}\text { Non-Asian } \\
\quad \text { countries: all }\end{array}$ & $\begin{array}{l}\text { Negative } \\
\text { Positive }\end{array}$ & $\begin{array}{r}1,188 \\
284\end{array}$ & $\begin{array}{l}6.91 \\
5.68 \\
(<.0001)\end{array}$ & $\begin{array}{l}4.75 \\
3.98 \\
(<.0001)\end{array}$ & $\begin{array}{l}3.43 \\
3.45 \\
(.0002)\end{array}$ & $\begin{array}{l}2.96 \\
3.16 \\
(.3022)\end{array}$ & $\begin{array}{l}2.87 \\
2.70 \\
(.3011)\end{array}$ & $\begin{array}{l}4.04 \\
3.42 \\
(<.0001)\end{array}$ & $\begin{array}{c}-48.56 \% * * * \\
-42.02 \% * * * \\
(<.0001)\end{array}$ & $\begin{array}{l}(<.0001) \\
(<.0001)\end{array}$ & $\begin{array}{l}7.61 \% * * * \\
6.68 \% \\
(<.0001)\end{array}$ & $\begin{array}{l}(.0097) \\
(.1984)\end{array}$ \\
\hline $\begin{array}{l}\text { Difference Asian: } \\
\text { Non-Asian } \\
(p \text { value })\end{array}$ & $\begin{array}{l}\text { Negative } \\
\text { Positive }\end{array}$ & & $\begin{array}{l}(.0658) \\
(.0485)\end{array}$ & $\begin{array}{l}(.0865) \\
(.0000)\end{array}$ & $\begin{array}{l}(.2453) \\
(.0000)\end{array}$ & $\begin{array}{l}(.3980) \\
(.0015)\end{array}$ & $\begin{array}{r}(.8811) \\
(<.0001)\end{array}$ & $\begin{array}{l}(.5118) \\
(.0060)\end{array}$ & $\begin{array}{l}(.2016) \\
(.9237)\end{array}$ & & $\begin{array}{l}(.9428) \\
(.4001)\end{array}$ & \\
\hline
\end{tabular}

NotE.-Median EBITDA to Interest Expense, where EBITDA are the company's earnings before total interest expense, depereciation, amortization and provisions. Tests of significance are based on a Wilcoxon signed rank test. The third row in every panel is the p-value for a two tailed test of equal medians in negative and positive exchange rate beta firms. We also report the p-value but a test of equality of median crisis vs. no crisis sample, as well as Asian vs. non Asian countries.

$*, * *$ and $* * *$ indicate that the coefficient is significantly different from zero at the $0.1,0.05$ and 0.01 levels or better, respectively. 
firms in Asia. This implies that Asian companies did not earn enough revenue to cover their interest expenses.

\section{Investments}

We analyzed the investment policies in our sample of firms from three different regions by obtaining data on changes in total assets. We define net investments as the ratio of changes in total assets relative to total assets in the previous period. In Table 11, we summarize changes in net investments for a period of 6 years.

Overall in our crisis sample, negative-ERB companies invest less than they did before the onset of a currency crisis. (a decline of $7.10 \%$, significant at the $1 \%$ level), whereas there is no change for the positiveERB companies. In our control sample, both negative- and positiveexposure firms increased their investments. Among the regions in our crisis sample, Asia stands out once more: Both types of firms increased their investments in the 2 years before the crisis (increases of $4.88 \%$ and $2.25 \%$ for negative- and positive-exposure firms, respectively). Moreover, the investment levels for Asian firms are high until the crisis. In this respect, Asia is different from Europe and Latin America. Claessens et al. (1998) report, in line with our results, relatively higher investment rates (measured as new dollar investments as a share of existing fixed assets) in Asian firms than in U.S. and German firms. Consistent with Schneider and Tornell's (2001) model, the positiveexposure firms grow more in the years preceding a currency crisis in all the regions.

Asian investment patterns differ from those of Europe and Latin America also after the currency depreciations. Both negative- and positive-ERB firms in Asia showed decreases in the investment rate after the crisis. Two years after the crisis, the negative exposure firms in Asia are actually downsizing, not just growing at a slower rate. In Europe and Latin America, the negative-ERB firms increased their investment rates.

\section{Summary of the Findings}

Our analysis suggests that firms in countries that suffered dramatic exchange rate depreciations in the last decade follow a similar pattern of financial policies prior to a currency crisis. We documented significant increases in leverage in the 2 years preceding a currency depreciation. These increases in leverage are greater for negativeexposure firms in our crisis sample, whereas for the control sample, the opposite holds. We also showed a decline in profitability in the corporate sector. The decline is sharper for the firms with negative exposure to exchange rate movements. Again, the evidence for the control sample is very different. The major difference between Asian 


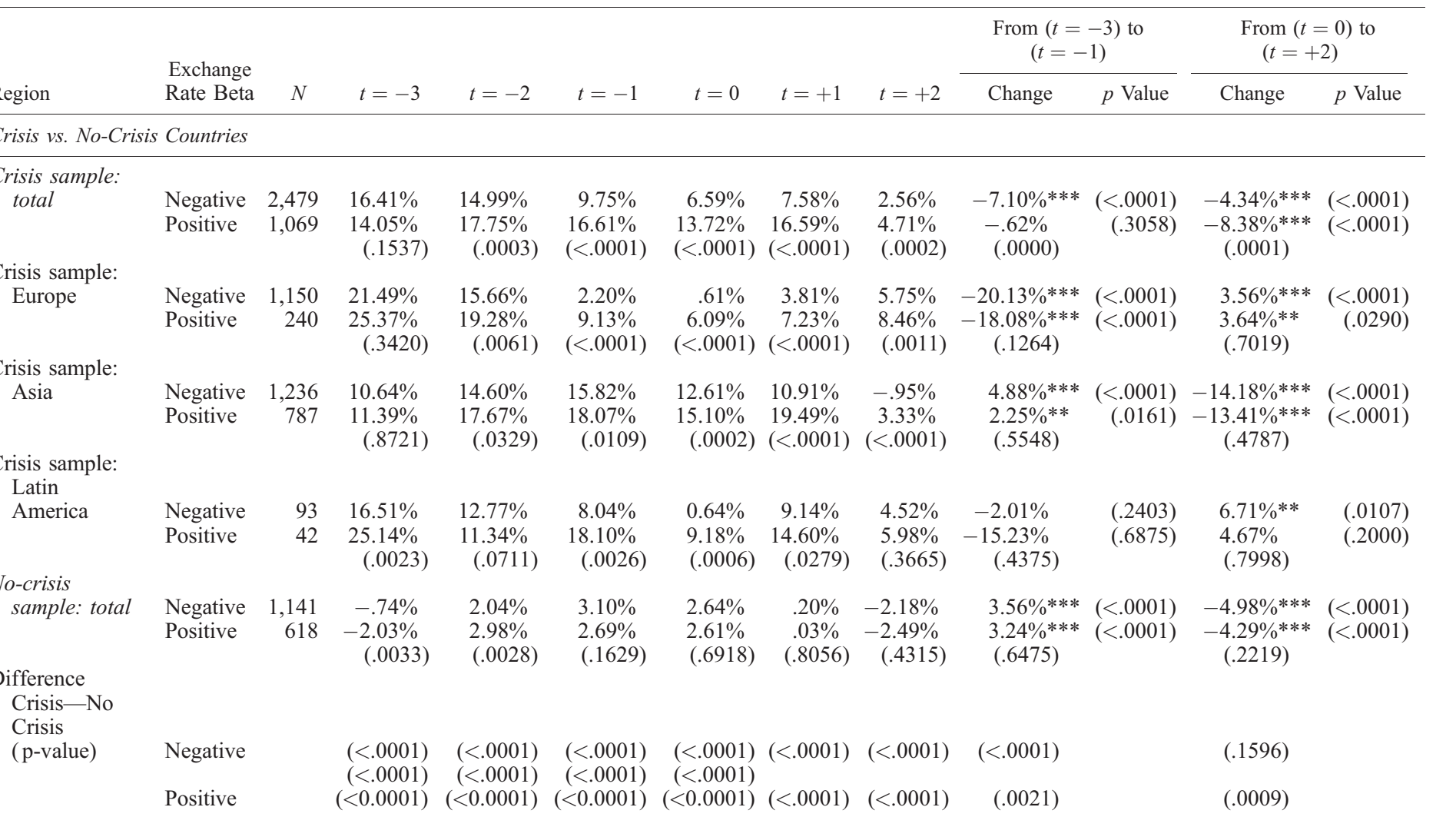


Asian vs. Non-Asian Countries

\begin{tabular}{|c|c|c|c|c|c|c|c|c|c|c|c|c|}
\hline \multicolumn{13}{|l|}{ Asian countries: } \\
\hline & $\begin{array}{l}\text { Negative } \\
\text { Positive }\end{array}$ & $\begin{array}{l}2,401 \\
1,567\end{array}$ & $\begin{array}{c}3.22 \% \\
1.78 \% \\
(<.0001)\end{array}$ & $\begin{array}{c}0.08 \% \\
8.05 \% \\
(<.0001)\end{array}$ & $\begin{array}{l}7.79 \% \\
9.11 \% \\
(.5500)\end{array}$ & $\begin{array}{l}6.30 \% \\
8.62 \% \\
(.1293)\end{array}$ & $\begin{array}{l}3.58 \% \\
7.79 \% \\
(.7254)\end{array}$ & $\begin{array}{c}-1.80 \% \\
-.35 \% \\
(<.0001)\end{array}$ & $\begin{array}{l}3.93 \% * * * \\
3.07 \% * * * \\
(<.0001)\end{array}$ & $\begin{array}{l}(<.0001) \\
(<.0001)\end{array}$ & $\begin{array}{c}-7.60 \% * * * \\
-7.25 \% * * * \\
(.0000)\end{array}$ & $\begin{array}{l}(<.0001) \\
(<.0001)\end{array}$ \\
\hline $\begin{array}{l}\text { Non Asian } \\
\quad \text { countries: all }\end{array}$ & $\begin{array}{l}\text { Negative } \\
\text { Positive }\end{array}$ & $\begin{array}{r}1,280 \\
313\end{array}$ & $\begin{array}{l}21.39 \% \\
25.37 \% \\
(<.0001)\end{array}$ & $\begin{array}{l}15.48 \% \\
17.48 \% \\
(<.0001)\end{array}$ & $\begin{array}{c}2.83 \% \\
9.40 \% \\
(<.0001) \\
(<0.001)\end{array}$ & $\begin{array}{r}.61 \% \\
6.27 \% \\
(<.0001)\end{array}$ & $\begin{array}{l}4.29 \% \\
7.23 \% \\
(.0241)\end{array}$ & $\begin{array}{l}5.49 \% \\
8.22 \% \\
(<.0001)\end{array}$ & $\begin{array}{c}-19.21 \% * * * \\
-18.08 \% * * * \\
(<.0001)\end{array}$ & $\begin{array}{l}(.0000) \\
(.0000)\end{array}$ & $\begin{array}{l}3.82 \% * * * \\
3.58 \% * * \\
(<.0001)\end{array}$ & $\begin{array}{l}(.0000) \\
(.0247)\end{array}$ \\
\hline $\begin{array}{l}\text { Difference Asian- } \\
\text { Non-Asian } \\
(p \text { value })\end{array}$ & $\begin{array}{l}\text { Negative } \\
\text { Positive }\end{array}$ & & $\begin{array}{l}(.0695) \\
(.0026)\end{array}$ & $\begin{array}{l}(.0013) \\
(.0009)\end{array}$ & $\begin{array}{r}(<.0001) \\
(.0139)\end{array}$ & $\begin{array}{l}(<.0001) \\
(<.0001)\end{array}$ & $\begin{array}{l}(<.0001) \\
(<.0001)\end{array}$ & $\begin{aligned} &(.0013) \\
&(<.0001)\end{aligned}$ & $\begin{array}{l}(.0661) \\
(.3105)\end{array}$ & & $\begin{array}{l}(.3039) \\
(.8122)\end{array}$ & \\
\hline
\end{tabular}

Note.-Median Net Investment. Net Investment is defined as the ratio of the change in total assets to total assets. Tests of significance are based on a Wilcoxon signed rank test. The third row in every panel is the p-value for a two-tailed test of equal medians in negative and positive exchange rate beta forms. We also report the p-value for a test of equality of medians crisis vs. no crisis sample, as well as Asian vs. non Asian countries.

$*, * *$ and $* * *$ indicate that the coefficient is significantly different from zero at the $0.1,0.05$ and 0.01 levels or better, respectively. 
companies and other companies in the precrisis period is that Asian companies kept on investing a lot.

We can document significant differences across regions in the years following a currency depreciation. In Europe and Latin America, the performance of negative-ERB firms improved or at least did not get any worse, while in Asia, the performance of all firms were worse after the onset of the crisis. The evidence in Europe fits quite well with the predictions of Bris and Koskinen (2002), whereas the implications of Aghion et al. (2001) are more consistent with the Asian evidence. Overall, the evidence gives support to the Schneider and Tornell (2004) model to the extent that firms with negative- and positive-exchange rate exposures correspond to firms in tradable and nontradable sectors.

Next we study cross-sectionally the determinants of a firm leverage prior to the currency crises.

\section{Cross-Sectional Analysis on Firm Leverage}

We complete the analysis by testing whether firms' leverage prior to a currency depreciation can be explained partially by their exposure to currency movements. If financial distress is likely to induce a government to let the currency depreciate as a way of bailing out companies, as postulated by Bris and Koskinen (2002), then we should expect firms that benefit the most from a currency depreciation to have a higher leverage than companies that suffer from depreciation prior to a currency crisis. So far, we have showed, in a simple time-series framework, that negative-exposure companies increase their leverage more than positive-exposure companies. At the same time, we know that negative-exposure-firm profitability declines more than positiveexposure-firm profitability during the precrisis period. Hence, the increasing leverage for negative-exposure firms could be just an accounting artifact, resulting from accumulating losses. Studying leverage in a cross-sectional regression allows us to control for profitability and other firm-specific characteristics, and as a result, we can get a more reliable evidence about the role of currency exposure in determining the leverage choices of the firms.

We performed cross-sectional regression analyses at the firm level, where the dependent variable is the firm's debt-to-value ratio (book values) as of December prior to the corresponding currency crisis. The set of explanatory variables includes the firm's exchange rate beta, calculated over a window of $t=-6$ to $t=-24$ months relative to the event month. We construct a dummy variable $I_{i}$ that takes value 1 if the corresponding firm $i$ belongs to the crisis sample, and 0 if it belongs to the control sample. We then decomposed the effect of the exchange rate beta into two groups, depending on the dummy variable. The first component equals $I_{i} \beta_{i}^{x}$ described in table 12 as Exchange rate beta, 


\begin{tabular}{|c|c|c|c|c|c|c|c|c|}
\hline \multirow[b]{2}{*}{ Variable } & \multicolumn{2}{|c|}{ Model I } & \multicolumn{2}{|c|}{ Model II } & \multicolumn{2}{|c|}{ Model III } & \multicolumn{2}{|c|}{ Model IV } \\
\hline & Estimate & $p$ Value & Estimate & $p$ Value & Estimate & $p$ Value & Estimate & $p$ Value \\
\hline Intercept & & & -.1727 & $(.1178)$ & & & & \\
\hline \multicolumn{9}{|l|}{ Exchange rate } \\
\hline beta, crisis sample & $-.0229 \% * * *$ & $(<.0001)$ & $-.0210 * * *$ & $(.0094)$ & $-.0237 * * *$ & $(.0043)$ & $-.0241 * * *$ & $(.0059)$ \\
\hline \multicolumn{9}{|l|}{ Exchange rate } \\
\hline beta, no-crisis sample & -.0007 & $(.7137)$ & $.1211^{* * *}$ & $(.0041)$ & $.1396^{* * *}$ & $(.0012)$ & $.1382 * * *$ & $(.0014)$ \\
\hline Firm size & $.0231 * * *$ & $(<.0001)$ & $1.0163 * * *$ & $(<.0001)$ & $.0229 * * *$ & $(<.0001)$ & $.0234 * * *$ & $(<.0001)$ \\
\hline EBIT/total assets & -.0101 & $(.3309)$ & $-.0056 * * *$ & $(.0027)$ & $-.0082 * * *$ & $(<.0001)$ & $-.0097 * * *$ & $(<.0001)$ \\
\hline Market-to-book ratio & .0002 & $(.2391)$ & .0001 & $(.4968)$ & .0002 & $(.4073)$ & .0001 & $(.4236)$ \\
\hline \multicolumn{9}{|l|}{ Corruption index } \\
\hline $\begin{array}{l}\text { (lower score, } \\
\text { high corruption) }\end{array}$ & & & -.0242 & $(.5926)$ & $-.1855 * * *$ & $(.0003)$ & $-.1349 *$ & $(.0505)$ \\
\hline \multicolumn{9}{|l|}{ Efficiency of } \\
\hline judicial system & & & $-.0043-0.0043$ & $(.6981)$ & .0152 & $(.1686)$ & .0170 & $(.1711)$ \\
\hline Enforceability of contracts & & & $-.1148 * *$ & $(.0104)$ & .0572 & $(.3056)$ & $-.1682 *$ & $(.0830)$ \\
\hline Log GDP per capita & & & .0196 & $(.4428)$ & $.1065 * * *$ & $(<.0001)$ & $.0981 * *$ & $(.0136)$ \\
\hline \multicolumn{9}{|l|}{ Risk of expropriation } \\
\hline (lower score, high risk) & & & -.0185 & $(.6553)$ & $-4818 * * *$ & $(<.0001)$ & $-.2916^{* * *}$ & $(.0070)$ \\
\hline $\begin{array}{l}\text { Government repudiation } \\
\text { of contracts (lower score, } \\
\text { high risk) }\end{array}$ & & & $.0750 * * *$ & $(.0001)$ & .0211 & $(.2323)$ & $.1217 * * *$ & $(.0001)$ \\
\hline
\end{tabular}


TABLE 12 (Continued)

\begin{tabular}{|c|c|c|c|c|c|c|c|c|}
\hline \multirow[b]{2}{*}{ Variable } & \multicolumn{2}{|c|}{ Model I } & \multicolumn{2}{|c|}{ Model II } & \multicolumn{2}{|c|}{ Model III } & \multicolumn{2}{|c|}{ Model IV } \\
\hline & Estimate & $p$ Value & Estimate & $p$ Value & Estimate & $p$ Value & Estimate & $p$ Value \\
\hline Rule of Law & & & -.0012 & $(.9597)$ & $.1201 * * *$ & $(.0005)$ & .0271 & $(.4502)$ \\
\hline Dummy for & & & & & & & & \\
\hline Asian countries & & & & & $-.0929 * * *$ & $(.0001)$ & $-.2213 * * *$ & $(<.0001)$ \\
\hline Dummy for & & & & & & & & \\
\hline European countries & & & & & $-.2355^{* * *}$ & $(.0002)$ & $-.2812 * * *$ & $(.0004)$ \\
\hline Dummy for Latin & & & & & & & & \\
\hline American countries & & & & & $-.5982 * * *$ & $(<.0001)$ & $-.6034 * * *$ & $(<.0001)$ \\
\hline Legal mother is Germany & & & & & & & $-.3281 * * *$ & $(.0001)$ \\
\hline Legal Mother is & & & & & & & & \\
\hline France and Spain & & & & & & & -.1586 & $(.1903)$ \\
\hline Legal mother is & & & & & & & & \\
\hline United Kingdom & & & & & & & $-.1050 * *$ & $(.0136)$ \\
\hline Number of observations & 3211 & & 2972. & & 2970 & & 2967 & \\
\hline$R$ square & .963 & & .086 & & .574 & & .575 & \\
\hline
\end{tabular}

NoтE.- This table reports the results of the regression of a firm's debt-to-value ration on the variables listed under the variables column for countries that have suffered a currency crises in the period 1985-2000. The debt-to-value ratio is calculated dividing total debt by the sum of total debt plus the book value of equity. The variables "Exchange Rate Beta-Crisis Sample" and "Exchange Rate Beta-No Crisis Sample" are dummy variables that equal the Exchange Rate Beta of the firm in question or zero, depending on whether the firm belongs to a country in crisis or the non-crisis sample, respectively. Exchange rates and accounting variables are from Datastream. The corporate governance variables are from La Porta et al. (1998). P-values have been corrected for heteroskedasticity following the approach in White (1980). All R-squares are adjusted Model I is estimated with country-fixed effects.

$*, * *$ and $* * *$ indicate that the coefficient is significantly different from zero at the $0.1,0.05$ and 0.01 levels or better, respectively. 
crisis sample. The second component equals $\left(1-I_{i}\right) \beta_{2}^{x}$ described as Exchange rate beta, no-crisis sample. The procedure allows us to disentangle the effect of the exchange rate regime in a joint estimation.

La Porta et al. (1998) argue that laws affecting investor protection have consequences for corporate finance. We therefore control in our analysis for differences in efficiency of the judicial system, rule of law, corruption, and risk of expropriation across countries. The variables reported in La Porta et al. (1998) are averages calculated over different time horizons, so their interpretation must be taken with caution. For instance, the efficiency of the judiciary system is calculated by La Porta et al. (1998) as the average between 1980 and 1993, while the start of currency crises we consider dates from 1992. In our regressions, we therefore employ the complete time series of data that La Porta et al. use in their paper, ${ }^{20}$ and calculate when possible the 5 -year average prior to the corresponding currency crisis date. Comparing the mean values of the variables in our sample with all the countries considered by La Porta et al. (1998) we observe no dramatic differences (the mean values for the variables Efficiency of the judicial system, Rule of Law, Corruption, and Risk of expropriation are 7.10, 6.78, 6.59, and 7.96 for our sample and $7.67,6.85,6.9$, and 8.05 , for a total sample of 49 countries in La Porta et al.).

Rajan and Zingales (1995) argue that highly levered companies are more likely to give up profitable investment opportunities. Hence, growth opportunities (using the market value of assets divided by the book value of assets as a proxy) should be negatively related to debtto-equity ratios. We calculate the average market-to-book ratio in the 3 years preceding the currency crises for 3211 firms in our sample. In Rajan and Zingales (1995), size is measured by the logarithm of sales. They obtain a positive coefficient in their regressions, although, in their view, a negative relationship between size and debt levels is sensible if size is also a proxy for the information outside investors have. Our measure of size is a 3-year average of a firm's sales before the relevant currency depreciation. Additionally, Rajan and Zingales (1995) find a negative relationship between earnings (earnings before interest, taxes, and depreciation normalized by the book value of assets) and book debt-to-value ratios. Our measure of profitability is EBIT normalized by total assets. We further control for the log of the GDP per capita in dollars. In addition, in Model I we also employ firm-level fixed effects.

The results from the regression are reported in table 12. For the total sample, we find results consistent with Rajan and Zingales (1995), since profitability and size have, respectively, negative and positive coefficients in general. Contrary to Rajan and Zingales (1995), the

20. We are grateful to Florencio López de Silanes for providing us with this unpublished data. 
market-to-book ratio is never significant in our cross-sectional regressions. Focusing on the coefficient for the exchange rate beta, we consistently find a negative relationship between a firm's exposure to exchange rate movements and book leverage for the firms in our crisis sample. The opposite holds for the firms in the control sample. This means that negative-exposure firms have higher leverage than positive exposure firms for our crisis sample, even when we control for the relevant firm characteristics. This finding is consistent with the arguments in Bris and Koskinen (2002). We also find that some corporate governance variables help explain leverage, albeit sometimes the coefficients are not significant. The corruption index and risk of expropriation get negative coefficients, which are to be expected: High corruption and high risk of expropriation lead to increasing leverage.

\section{Conclusions}

This paper uses company-level data from 17 countries that experienced a currency crisis during the past decade. We also include data from three control countries, whose currencies were under attack but remained quite stable. First, we studied leverage on the company-level before and after the currency crises. We documented increasing leverage before the onset of the crises for Europe, Asia, and Latin America. After the respective crises, we show that leverage further increases in Asia and Latin America but not in Europe. Furthermore, the increasing leverage during the pre- and postcrisis periods is confined to the countries forced to devalue their currencies during the crisis.

Next, we sort companies into two groups, depending on whether they benefited from or were harmed by currency appreciations. The sorting is done using companies' individual stock returns regressed on the home currency's movement against the U.S. dollar and on the part of market return orthogonal to the currency movement. Using this grouping, we show that there are differences in companies' leverage and profitability depending on their exchange rate exposure in our crisis sample. While leverage increases and profitability declines for all companies, these effects are more pronounced for negative-exchange-rate-exposure companies. We find the opposite for our control sample. Moreover, there are clear differences between the regions. For the European firms that have negative-exchange-rate exposure, we document that leverage increases and profitability decreases before the crisis, but the financial health of these companies improves after the crisis. Therefore, there is evidence that currency depreciations helped the European negativeexposure companies. For Asian firms, leverage increases and profitability decreases both before and after the currency depreciations, albeit the negative-exposure companies suffer more during the precrisis period and less during the postcrisis period. We can conclude that currency 
depreciations did not help improve the financial health of Asian companies. The evidence for Latin America is mixed, and the Latin American situation lays somewhere between the European and Asian ones. Regarding financial fragility, we find that all firms in our crisis sample become more fragile before the onset of the crisis. Interestingly, there is evidence that again the Asian crisis differs from crises in Europe and Latin America: Firms in Asia became even more fragile after the crises, especially when the negative-exposure firms in Europe and Latin America start to recover. In addition, net investments also confirm that the Asian crisis was different. In Asia, investments increased prior to the crisis and declined afterward, while the patterns are the opposite for Europe and Latin America.

The time-series evidence documented could be partially a result of accounting identities resulting from low or even negative profitability. Hence, the time-series evidence does not prove any kind of strategic behavior on the part of the negative-exchange-rate-exposure firms. We address this problem in a cross-sectional regression controlling for firm characteristics, including profitability. We find that the firms with negative-exchange-rate exposures have higher leverage prior to a crisis than firms that have positive-exchange-rate betas. The results of higher leverage, higher financial fragility, and lower profitability for negativeexposure companies are consistent with the arguments in Bris and Koskinen (2002), whereas the evidence that all kinds of firms suffer from these problems is consistent with Aghion et al. (2001). The results of recovery among negative-exposure firms, especially in Europe, show that currency depreciations have helped solve balance sheet problems, as argued by Bris and Koskinen (2002). We also provide evidence from Asia consistent with Aghion et al. (2001): All firms in Asia have lower profitability and are more fragile even after a currency depreciation. In all the crisis regions, we established that, prior to the crises, the positive-exposure firms fared better than the negative-exposure firms and the roles were reversed after the crises. This asymmetrical pattern is consistent with Schneider and Tornell (2004), if our classification of firms to negative- and positive-exposure firms corresponds to the firms belonging to the tradable and nontradable sectors. Also, the observation that positive-exposure companies grow faster than negative-exposure companies is in accordance with Schneider and Tornell (2004).

The evidence that negative exposure firms suffer more prior to currency crises is also consistent with Aghion et al. (2001). In that paper, the declining profits for firms that produce a tradable good is due to increasing costs not firm-level strategic behavior, as in Bris and Koskinen (2002). However, the evidence that negative-exposure firms increase their leverage more than declining profits would dictate hints at strategic behavior by the firms. 
The results provided in this paper could also be consistent with the corporate governance explanations explored by Johnson et al. (2000), Lemmon and Lins (2003), and Mitton (2002). These papers show, providing either country- or firm-level evidence, that the magnitude of the crisis was negatively related to corporate governance measures in Asia. While these papers concentrate on economic development on a country or firm level during the crisis, they do not provide adequate explanation on what caused the crisis. One feasible way for deficiencies in corporate governance to propagate a currency crisis is through increased leverage. We try to examine this issue in our cross-sectional regression, using country-level variables of corporate governance. The results give some support to the view that corporate governance plays an independent role in increasing corporate leverage. However, a word of caution is needed: To properly study the effects of corporate governance, firm-level variables should be used. While we can see the merit of this approach, this is beyond the scope of this paper.

Whether the corporate sector's choice between foreign and domestic debt affects the probability and the severity of currency crises is still an open question. The measure of leverage we report in this paper does not distinguish among different sources of debt financing. However, by estimating measures of exchange rate exposure on a firm level, we can at least partially deal with this problem. Disaggregated data on debt financing for emerging and developing economies, such as the ones we consider, is not easily available, so indirect measures are necessary. The analysis, however, has interesting implications and deserves further research.

\section{References}

Adler, M., and E. B. Dumas. 1983. International portfolio choice and corporation finance: A synthesis. Journal of Finance 38 (June): 925-84.

Aghion, P., P. Bacchetta, and A. Banerjee. 2001. Currency crises and monetary policy in an economy with credit constraints. European Economic Review 45 (June): 1121-50.

Aghion, P., P. Bacchetta, and A. Banerjee, 2004, Financial Development and the Instability of Open Economics, Journal of Monetary Economics, in press.

Allayannis, G., and J. Ihrig, 2001, Exposure and Markups, Review of Financial Studies 14: 805-35.

Allayannis, G., G. W. Brown, and L. Klapper, 2003, Capital Structure and Financial Risk: Evidence from Foreign Debt Use in East Asia, Journal of Finance 58:2667-2710.

Amihud, Y. 1994. Exchange rates and the valuation of equity shares. In: Exchange rates and corporate performance, ed. Y. Amihud and R. M. Levich. New York: Irwin.

Bailey, W., and Y. P. Chung. 1995. Exchange rate fluctuations, political risk, and stock returns: Some evidence from an emerging market. Journal of Financial and Quantitative Analysis 20 (December): 541-61.

Bartov, E., and G. M. Bodnar. 1994. Firm valuation, earnings expectations, and the exchange-rate exposure effect. Journal of Finance 49 (December): 1755-85.

Bodnar, G. M., and W. Gentry. 1993. Exchange rate exposure and industry characteristics: Evidence from Canada, Japan, and the U.S. Journal of International Money and Finance 12 (February): 29-45. 
Bodnar, G. M., and M. H. F. Wong. 2000. Estimating exchange rate exposures: Some "weighty" issues. Working Paper No. W7497. National Bureau of Economic Research, Cambridge, MA.

Bris, A., and Y. Koskinen. 2002. Corporate leverage and currency crises. Journal of Financial Economics 63 (February): 275-310.

Claessens S., S. Djankov, and L. Lang, 1998, East Asian Corporates: Growth, Financing, and Risks over the last Decade, Malaysian Journal of Economics 35:137-256.

Corsetti, G., P. Pesenti, and N. Roubini. 1999. Paper tigers? A model of the Asian crisis. European Economic Review 43 (June): 1211-36.

Domínguez, K., and L. Tesar, 2001, A Re-Examination of Exchange Rate Exposure, American Economic Review, Papers \& Proceedings. (May): 367-70.

Dumas, B., and B. Solnik. 1995. The world price of foreign exchange risk. Journal of Finance 50 (June): 445-79.

Dumas, Bernard. 1978. The theory of the trading firm revisited. Journal of Finance 33 (June): 1019-30.

Harvey, C. R., and A. H. Roper. 1999. The Asian bet. In: The crisis in emerging financial markets, ed. A. Harwood, R. E. Litan, and M. Pomerleano. Washington DC: Brookings Institution Press.

Hodder, J. E. 1982. Exposure to exchange-rate movements. Journal of International Economics 13(3-4) (November): 375-86.

Johnson, S., P. Boone, A. Breach, and E. Friedman. 2000. Corporate governance in the Asian Financial crisis. Journal of Financial Economics 58 (October): 141-86.

Jorion, Philippe. 1990. The exchange rate exposure of U.S. multinationals. Journal of Business 63 (July): 331-45.

Jorion, Philippe. 1991. The pricing of exchange rate risk in the stock market. Journal of Financial and Quantitative Analysis 26 (September): 363-76.

Kaminsky, G., and C. M. Reinhart. 1996. The twin crises: The causes of banking and balance-of payment problems. Working Paper. Washington, DC: Federal Reserve Board.

Krugman, Paul. 1999. Balance sheets, the transfer problem, and financial crises. In: International finance and financial crises, essays in honor of Robert P. Flood, ed. P. Isard, A. Razin, and A. Rose (Eds.). New York: Kluwer Academic Publishers.

La Porta, R., F. López-de-Silanes, A. Shleifer, and R. W. Vishny. 1998. Law and finance. Journal of Political Economy 106 (December): 1113-55.

Lemmon, M., and K. Lins. 2003. Ownership structure, corporate governance and firm value: Evidence from the Asian financial crisis. Journal of Finance 58:1445-68.

Mitton, T. 2002. A cross-firm analysis of the impact of corporate governance on the East Asian financial crisis. Journal of Financial Economics 64 (May): 215-41

Organization for Economic Cooperation and Development. 1999: Asia and the global crisis: The industrial dimension. Paris: OECD.

Pomerleano, M. 1998. The East Asia crisis and corporate finances. The untold micro story. Emerging Markets Quarterly 2 (Winter): 14-27.

Radelet, S., and J. Sachs. 1998. The onset of the East Asian financial crisis. Working Paper No. 6680. National Bureau of Economic Research, Cambridge, MA.

Rajan, R. G., and L. Zingales. 1995. What do we know about capital structure? Some evidence from international data. Journal of Finance 50 (December): 1421-60.

Schneider, M., and A. Tornell. 2004. Balance Sheet Effects, Bailout Guarantees and Financial Crises, Review of Economic Studies 71:883-913. 